\title{
Article \\ Human Lung-Resident Macrophages Express and Are Targets of Thymic Stromal Lymphopoietin in the Tumor Microenvironment
}

\author{
Mariantonia Braile ${ }^{1,2}$, Alfonso Fiorelli ${ }^{3}\left(\mathbb{D}\right.$, Daniela Sorriento ${ }^{4}$ (D), Rosa Maria Di Crescenzo ${ }^{3}$, \\ Maria Rosaria Galdiero ${ }^{1,2,5}$, Gianni Marone ${ }^{1,2,5}(\mathbb{D})$, Mario Santini ${ }^{3}\left(\mathbb{D}\right.$, Gilda Varricchi ${ }^{1,2,5, *(\mathbb{D})}$ \\ and Stefania Loffredo $1,2,5, *$ (D)
}

Citation: Braile, M.; Fiorelli, A.; Sorriento, D.; Di Crescenzo, R.M.; Galdiero, M.R.; Marone, G.; Santini, M.; Varricchi, G.; Loffredo, S. Human Lung-Resident Macrophages Express and Are Targets of Thymic Stromal Lymphopoietin in the Tumor Microenvironment. Cells 2021, 10, 2012. https://doi.org/10.3390/ cells10082012

Academic Editors: Fabrizio Mattei, Yona Keisari and Carlos Alfaro

Received: 6 July 2021

Accepted: 3 August 2021

Published: 6 August 2021

Publisher's Note: MDPI stays neutral with regard to jurisdictional claims in published maps and institutional affiliations.

Copyright: (c) 2021 by the authors. Licensee MDPI, Basel, Switzerland. This article is an open access article distributed under the terms and conditions of the Creative Commons Attribution (CC BY) license (https:// creativecommons.org/licenses/by/ $4.0 /)$.

1 Center for Basic and Clinical Immunology Research (CISI), Department of Translational Medical Sciences, University of Naples Federico II, 80131 Naples, Italy; brailemariantonia@gmail.com (M.B.); mariarosaria.galdiero@unina.it (M.R.G.); marone@unina.it (G.M.)

2 WAO Center of Excellence, 80131 Naples, Italy

3 Department of Translational Medical and Surgical Science, University of Campania Luigi Vanvitelli, 80131 Naples, Italy; alfonso.fiorelli@unicampania.it (A.F.); rosa.dicrescenzo@unina.it (R.M.D.C.); mario.santini@unicampania.it (M.S.)

4 Department of Advanced Biomedical Sciences, University of Naples Federico II, 80131 Naples, Italy; daniela.sorriento@unina.it

5 Institute of Experimental Endocrinology and Oncology (IEOS), National Research Council, 80131 Naples, Italy

* Correspondence: gildanet@gmail.com (G.V.); stefanialoffredo@hotmail.com (S.L.)

\begin{abstract}
Thymic stromal lymphopoietin (TSLP) is a pleiotropic cytokine highly expressed by epithelial cells and several innate and adaptive immune cells. TSLP exerts its biological effects by binding to a heterodimeric complex composed of TSLP receptor (TSLPR) and IL-7R $\alpha$. In humans, there are two TSLP isoforms: the short form (sfTSLP), constitutively expressed, and the long form (lfTSLP), which is upregulated in inflammation. TSLP has been implicated in the induction and progression of several experimental and human cancers. Primary human lung macrophages (HLMs), monocyte-derived macrophages (MDMs), and peripheral blood monocytes consitutively expressed sfTSLP mRNA. Incubation of HLMs, MDMs, and monocytes with lipopolysaccharide (LPS) or IL-4, but not with IL-13, induced TSLP release from HLMs. LPS, but not IL-4 or IL-13, induced CXCL8 release from HLMs. LPS, IL-4 alone or in combination with IL-13, induced the expression of lfTSLP, but not of sfTSLP from HLMs. Preincubation of HLMs with IL-4, alone or in combination with IL-13, but not IL-13 alone, synergistically enhanced TSLP release from LPS-activated macrophages. By contrast, IL-4, alone or in combination with IL-13, inhibited LPS-induced CXCL8 release from HLMs. Immunoreactive TSLP was detected in lysates of HLMs, MDMs, and monocytes. Incubation of HLMs with TSLP induced the release of proinflammatory (TNF- $\alpha$ ), angiogenic (VEGF-A, angiopoietin 2), and lymphangiogenic (VEGF-C) factors. TSLP, TSLPR, and IL-7R $\alpha$ were expressed in intratumoral and peritumoral areas of human lung cancer. sfTSLP and lfTSLP mRNAs were differentially expressed in peritumoral and intratumoral lung cancer tissues. The TSLP system, expressed in HLMs, MDMs, and monocytes, could play a role in chronic inflammatory disorders including lung cancer.
\end{abstract}

Keywords: angiogenesis; lymphangiogenesis; lung cancer; macrophages; monocytes; monocytederived macrophages; thymic stromal lymphopoietin; TSLP isoforms; tumor microenvironment

\section{Introduction}

Thymic stromal lymphopoietin (TSLP) is a pleiotropic cytokine [1,2] highly expressed by lung [3-8] and intestinal epithelial cells [9-14]. TSLP can be produced also by airway smooth muscle [15] and several immune cells, such as dendritic cells (DCs) [16], mast cells [3,17-19], eosinophils [20], and monocytes [16]. 
Human TSLP exerts its biological activities by binding to a high-affinity heteromeric complex composed of thymic stromal lymphopoietin receptor (TSLPR) and interleukin 7 receptor- $\alpha(\mathrm{IL}-7 \mathrm{R} \alpha)$ [21]. TSLP initiates signaling by establishing a ternary complex with its specific receptor, TSLPR, and then with IL-7R $\alpha[1,22,23]$.

Two isoforms (short and long) for TSLP have been identified in different human tissues $[9,13]$. The short-form TSLP (sfTSLP) is constitutively expressed in normal tissues, including bronchial and intestinal epithelial cells, keratinocytes, and lung fibroblasts [9,13,24-26], whereas the long-form TSLP (lfTSLP) is upregulated in inflammatory conditions [9,13]. Despite increasing evidence of a dichotomy for the two isoforms of TSLP in humans, the pathophysiological roles of sfTSLP and to some extent of IfTSLP are largely unknown [2]. There is also evidence that TSLP can be cleaved by endogenous proteases in inflammatory conditions [8,14,27].

The plethora of immune cell types that can either produce or respond to TSLP emphasizes the importance of this cytokine in multiple biological processes [1,2]. A novel and unexpected function of TSLP has been demonstrated in experimental and human cancers [2,28]. In particular, TSLP has been linked to the progression of several experimental [29-33] and human tumors [33-46]. By contrast, few studies have pointed to an anti-tumor role for TSLP in mouse models [47-51] and in human cancers [48]. It is important to emphasize that the differential expression and the functions of the two TSLP isoforms in human and experimental cancers are presently unknown.

Macrophages are important immune cells resident of all tissues [52], where they play pivotal roles in tissue homeostasis [53-55]. Tissue macrophages and peripheral blood monocytes represent two branches of the mononuclear phagocyte system, and they have complementary roles during immunological challenges [52]. Macrophages and monocytes are sentinels in immunity, combating infections [56], modulating angiogenesis and lymphangiogenesis [57-59], and surveilling agonist tumors [54,60-62]. Macrophages arise from different cell lineages emerging during embryonic development [63-66]. In the lung, tissue-resident macrophages homing during embryogenesis self-renew throughout life $[67,68]$. During inflammation, bone marrow-derived monocytes can invade the lung and differentiate into macrophages [67]. Macrophages are the predominant immune cells in human lung parenchyma [69-71]. Macrophages and monocytes are fundamental regulators of various aspects of tumor immunity [72,73]. In particular, human lung macrophages by producing proinflammatory cytokines (i.e., TNF- $\alpha$, CXCL8), proangiogenic (i.e., VEGF-A), and lymphangiogenic (i.e., VEGF-C) factors $[57,59,74]$ play a pivotal role in tumor initiation and growth [54].

The expression of TSLP receptor and TSLP isoforms by primary human lung macrophages (HLMs), monocytes and monocyte-derived macrophages (MDMs) has not been characterized. In this study, we evaluated the constitutive and LPS-induced expression of TSLPR, IL-7R $\alpha$ and TSLP isoforms (sfTSLP and lfTSLP) in HLMs, MDMs, and human peripheral blood monocytes. We also examined the effects of TSLP on the production of angiogenic and lymphangiogenic factors from HLMs and the expression of intratumoral and peritumoral TSLP system (i.e., TSLP receptor and TSLP isoforms) in human lung cancer.

\section{Materials and Methods}

\subsection{Reagents and Buffers}

The following were purchased: bovine serum albumin, L-glutamine, antibioticantimycotic solution $(10,000 \mathrm{IU} / \mathrm{mL}$ penicillin, $10 \mathrm{mg} / \mathrm{mL}$ streptomycin, and $25 \mu \mathrm{g} / \mathrm{mL}$ amphotericin B), RPMI 1640, fetal calf serum (FCS) (endotoxin level < $0.1 \mathrm{EU} / \mathrm{mL}$ ), peroxidase anti-peroxidase, hydrogen peroxide, diaminobenzidine, paraformaldehyde (PFA), Percoll $^{\circledR}$, Triton X-100 (Sigma-Aldrich, St. Louis, MO, USA), detoxified LPS (from E. coli serotype 0111:B4), M-CSF, TSLP, IL-13 and IL-4 (Miltenyi Biotec, Bologna, Italy), ELISA kits for TSLP, CXCL8, VEGF-A, VEGF-C, TNF- $\alpha$ (R\&D System, Minneapolis, MN, USA), RNeasy plus Minikit (Qiagen, Milan, Italy), high capacity cDNA RT (Life Technologies, Monza, Italy), and iTaqtm Universal SYBR ${ }^{\circledR}$ Green Supermix (Bio-Rad, Hercules, CA, 
USA). Flow cytometry was performed by the following Abs: anti-CD68 FITC, anti-CD163 FITC, anti-169 PE, anti-CD206 APC, anti-CD24 HV 450 (Miltenyi Biotec, Bologna, Italy), anti-CD5 PE, anti-CD123 APC, HLA-DR HV500, anti-CD22 APC (Becton Dickinson, Italy), anti-CD14 PE-Cy7 (Life-technologies, Monza, Italy), and anti-CD45 APC-Cy7 (BioLegend, Milan, Italy).

\subsection{Isolation and Purification of Human Lung Macrophages (HLMs)}

The study protocol was approved by the Ethics Committee of University of Naples Federico II (Prot. 7/19), and informed consent was obtained from donors. Macrophages were purified from macroscopically normal lung tissue obtained from 39 patients [hepatitis $\mathrm{C}$ virus (HCV-), hepatitis B surface Ag (HBsAg-), HIV-] (age 62.4 \pm 1.7 years) affected by lung adenocarcinoma undergoing thoracic surgery $[59,75]$. Freshly resected lung tissue was obtained intraoperatively and was minced finally with scissors and washed extensively with PIPES buffer over Nytex cloth $(120-\mu \mathrm{m}$ pore size (Tetko Elmsford, NY, USA). After Percoll gradient centrifugation, the cells were suspended $\left(10^{6}\right.$ cells $\left./ \mathrm{mL}\right)$ in RPMI 1640 with 5\% FCS, 2 mM L-glutamine, and 1\% antibiotic-antimycotic solution and incubated in 24-well plates (Falcon, Becton Dickinson, Milan, Italy). After $12 \mathrm{~h}$, the medium was removed and the plates were gently washed with RPMI. More than $98 \%$ of adherent cells were macrophages, as evaluated by flow-cytometric analysis [74].

\subsection{Flow Cytometry}

Human lung macrophages were suspended in PBS at a concentration of $5 \times 10^{6}$ cells $/ \mathrm{mL}$. Fifty $\mu \mathrm{L}$ of cell suspension were incubated $\left(20 \mathrm{~min}\right.$ at $\left.4{ }^{\circ} \mathrm{C}\right)$ with antibodies. To quench high spontaneous antifluorescence of HLMs, pellets were washed twice with PBS, suspended in $0.2 \mathrm{~mL}$ of Crystal violet solution (Certistain, Merck, Damstad, Germany) and incubation of $5 \mathrm{~min}$ at $22^{\circ} \mathrm{C}$. Adherent lung cells were examined initially by forward scatter (FSC) area versus side scatter (SSC) area and then by FSC area versus FSC height, with gating on single cells to eliminate dead cells, debris and clumped cells from the analysis. Single cells were then examined by CD45 expression, gating on $\mathrm{CD}_{4} 5^{+}$cells, which represented total leukocytes. The majority of the adherent lung cells were CD45 ${ }^{+}$leukocytes; within these cells, CD169 (siglec-1), CD206 (mannose receptors), CD68, CD163 and HLA-DR were used to identify macrophages as previously described $[70,74]$. The vast majority of CD169 ${ }^{+}$cells were human lung macrophages, which were $\mathrm{CD}_{206}{ }^{+}, \mathrm{CD}^{+} 8^{+}, \mathrm{CD}_{163}{ }^{+}$, and HLA-DR ${ }^{+}$. The remaining $\mathrm{CD}_{4} 5^{+}$cells were examined by (1) SSC-A versus CD14 to distinguish CD14 ${ }^{\text {high }}$ cells, which represent essentially monocytes (0.3\%); (2) SSC-A versus CD22 to identify CD22 ${ }^{\text {high }}$ cells that are B lymphocytes $(0.4 \%)$; (3) SSC-A versus CD5 to identify CD5 ${ }^{\text {high }}$ cells which represent $\mathrm{T}$ lymphocytes $(1.2 \%)$. Other minor contaminating cells were granulocytes and monocytes $(0.4 \%)$ [74]. The samples were acquired by FACS-Canto II and analysed by FACS-DiVa software (Becton Dickinson). Values were expressed as the percentage of positive and negative cells [74].

\subsection{Isolation of Monocytes and Differentiation of MDMs}

The study protocol involving the use of human blood was approved by the Ethics Committee of the University of Naples Federico II, and informed consent was obtained from blood donors (Prot. 301/12). Peripheral blood mononuclear cells were isolated from buffy coats of 32 healthy donors (HCV-, HBsAg-, and $\mathrm{HIV}-$ ) (age $47.6 \pm 2.3$ years) obtained from a leukapheresis unit. Leukocytes were separated from erythrocytes by dextran sedimentation [76]. Peripheral blood mononuclear cells (PBMCs) were purified by Histopaque-1077 (Sigma Aldrich, Milan, Italy) density gradient centrifugation $(400 \times g$ for 20 min at $22{ }^{\circ} \mathrm{C}$ ). Monocytes were further purified with CD14 microbeads according to the manufacturer's protocol (Miltenyi Biotec, Bologna, Italy). To obtain monocyte-derived macrophages (MDMs), monocytes $\left(1.5 \times 10^{6}\right.$ cells $\left./ \mathrm{cm}^{2}\right)$ were differentiated with M-CSF (50 ng/mL) for 7 days in RPMI 1640 supplemented with 10\% FCS (Sigma-Aldrich, Milan, Italy) [59]. 


\subsection{Cell Incubations}

HLMs, monocytes, and MDMs were cultured in 24-well plates in RPMI 1640 supplemented with 5\% FBS (Sigma-Aldrich, Milan, Italy), $2 \mathrm{mM}$ l-glutamine, and 1\% antibioticantimycotic solution.

The cells were treated with IL-13 (10 ng/mL) (Miltenyi Biotec, Bologna, Italy), IL-4 (10 ng/mL) (Miltenyi Biotec, Bologna, Italy), detoxified LPS $(100 \mathrm{ng} / \mathrm{mL})$ (from Escherichia coli serotype 0111:B4; Sigma-Aldrich, Milan, Italy), or TSLP $(5 \mathrm{ng} / \mathrm{mL})$ for $16 \mathrm{~h}$ or $6 \mathrm{~h}$ at $37^{\circ} \mathrm{C}$. In selected experiments, the cells were preincubated $\left(30 \mathrm{~min}, 37^{\circ} \mathrm{C}\right)$ with or without actinomycin $\mathrm{D}(1 \mu \mathrm{g} / \mathrm{mL})$ and then stimulated $\left(16 \mathrm{~h}, 37^{\circ} \mathrm{C}\right)$ with LPS or IL-4. At the end of incubation, the supernatants were collected and stored at $-80^{\circ} \mathrm{C}$ for subsequent ELISA quantification of cytokines. Lysis of the cells in the plates was carried out by using $0.1 \%$ Triton X-100 for total protein quantification by a Bradford-based assay (Bio-Rad, Segrate, MI, Italy).

\section{6. $m R N A$ Extraction and Quantitative PCR ( $q P C R)$ Analysis}

Total RNA was isolated with RNeasy plus Minikit (Qiagen, Milan, Italy) following manufacturer's instructions. RNA quality and integrity was estimated with 2100 Agilent Bionalyzer. Total mRNA was reverse-transcribed (high capacity cDNA RT, Life Technologies, Monza, Italy) and quantitative RT-PCR was carried out in Master Cycler realplex (Eppendorf, Milan, Italy) using iTaqtm Universal SYBR ${ }^{\circledR}$ Green Supermix (Bio-Rad, Hercules, CA, USA). GAPDH was used as housekeeping gene to normalize $\mathrm{Ct}$ (cycle threshold) values using the $2-\Delta \mathrm{Ct}$ formula. The following primer pairs were used: GAPDH: forward, $5^{\prime}$-GTCCACTGGCGTCTTCAC- $3^{\prime}$ and reverse, 5' -CTTGAGGCTGTTGTCATACTTC- $3^{\prime}$; sfTSLP: $5^{\prime}$-CCGCCTATGAGCAGCCAC- $3^{\prime}$ and $5^{\prime}$-CCTGAGTAGCATTTATCTGA- $3^{\prime}$; IfTSLP: $5^{\prime}$-CACCGTCTCTTGTAGCAATCG-3' ${ }^{\prime}$ and $5^{\prime}$-TAGCCTGGGCACCAGATAGC-3'; TSLPR: $5^{\prime}$-AGAGCAGCGAGACGACATTC- $3^{\prime}$ and $5^{\prime}$-CCGGTACTGAACCTCATAGAGG-3' ${ }^{\prime}$, IL7R $\alpha$ : $5^{\prime}$-TCGCAGCACTCACTGACC- $3^{\prime}$ and $5^{\prime}$-CGGGAAGGAGCCAATGAC- $3^{\prime}$. Targetspecific primers for sfTSLP, IfTSLP, TSLPR, IL-7R $\alpha$, and GAPDH were produced and purified by Custom Primers (Life Technologies, Milan, Italy).

\subsection{ELISA Assays}

Cytokine concentrations in supernatants and in cellular lysates were measured using commercially available ELISA kits for TSLP $(31.2-2000 \mathrm{pg} / \mathrm{mL})$, CXCL8 $(31.2-2000 \mathrm{pg} / \mathrm{mL})$, VEGF-A (31.3-2000 pg/mL), VEGF-C (109-7000 pg/mL), TNF- $\alpha$ (15.6-1000 pg/mL) (R\&D System, Minneapolis, MN, USA). Since the number of adherent macrophages and MDMs can vary among the wells and different experiments, the results were normalized for the total protein content in each well, determined in the cell lysates $(0.1 \%$ Triton X-100) by the Bradford assay. Cytokine release was expressed as pg of specific cytokine/mg of total proteins [77].

\subsection{Cytospin}

Cytospin of HLMs $\left(3 \times 10^{4}\right.$ cells $)$ was done in PBS containing $0.5 \%$ albumin by centrifugation ( $800 \mathrm{rpm}, 3 \mathrm{~min}, 22^{\circ} \mathrm{C}$ ) onto microscopic slides using a Shandon Cytospin 3 Cytocentrifuge (Shandon, Astmoor, UK). Slides were allowed to dry and stained with Diff-Quich (Biomap, Agrate Brianza, MB, Italy).

\subsection{Human Lung Tissue and HLM Immunohistochemistry}

Immunohistochemistry was performed as previously described (Sorriento, Molecular Cancer 2019). Peritumoral and intratumoral lung tissues were fixed in $10 \%$ buffered formalin and embedded in paraffin. Paraffin-embedded sections were processed for immunohistochemistry by peroxidase anti-peroxidase method using as primary antibody rabbit polyclonal anti-TSLP antibody (1:100) (PA5-78610), rabbit polyclonal antibody antiTSLP Receptor (PA5-203789, or rabbit polyclonal antibody anti-IL-7R $\alpha$ (1:100) (PA5-97870) (Invitrogen, Thermo Fisher Scientific, Monza, Italy). The secondary antibody was a goat 
anti-rabbit IgG (GtxRb-003-DHRPX, ImmunoReagents, Milan, Italy). The peroxidase was revealed in presence of $0.03 \%$ hydrogen peroxide and of the electron donor $(2.5 \%$ diaminobenzidine), which becomes visible as a brown precipitate. For negative controls, the primary antibody was omitted. Sections were then viewed with an Eclipse E1000 Fluorescence Microscope (Nikon) and acquired using Sigma Scan Pro software (Jandel). For immunocytochemistry analysis in HLMs, cells were cytospinned on microscope slides and processed as described above.

\subsection{Statistical Analysis}

The data are expressed as mean values \pm SD of the indicated number of experiments. Statistical analysis was performed in Prism 6 (GraphPad Software). Statistical analysis was performed by Student's T-test or one-way analysis of variance followed by Dunnett's test (when comparison was made against a control) or Bonferroni's test (when comparison was made between each pair of groups) by means of Analyse-it for Microsoft Excel, version 2.16 (Analyse-it Software, Ltd., Leeds, UK). Values of $p<0.05$ were considered significant.

\section{Results}

\subsection{TSLP Isoforms and TSLP Receptor in Human Lung Macrophages}

In a series of six different experiments, we investigated whether highly purified primary human lung macrophages (HLMs) constitutively express the TSLP receptor (TSLPR and IL-7R $\alpha$ ), the short-form TSLP (sfTSLP) and the long-form TSLP (lfTSLP) by different techniques. HLMs constitutively expressed sfTSLP mRNA (Figure 1A), whereas lfTSLP mRNA was barely detectable. Immunoreactive TSLP protein was detected in HLMs by immunohistochemistry (Figure 1C) and in lysed cells by ELISA $(2.36 \pm 1.29 \mathrm{pg} / \mathrm{mg}$ of protein). We also examined the constitutive expression of TSLPR and IL-7R $\alpha$ by two different techniques. HLMs expressed low levels of TSLPR and IL-7R $\alpha$ mRNAs (Figure 1A), whereas TSLPR (Figure 1D) and IL-7R $\alpha$ (Figure 1E) were detected by immunohistochemistry in HLMs. In particular, IL-7R $\alpha$ showed higher positive staining compared to TSLPR. Omission of the primary antibody resulted in negative staining (Figure 1B).

\subsection{Effects of IL-4, IL-13, and LPS on TSLP System in HLMs}

We have previously shown that LPS can activate HLMs to release several proinflammatory and immunomodulatory mediators $[59,75]$. $\mathrm{T}_{\mathrm{H}} 2$-like cytokines, IL-4 and IL-13, can synergize with LPS in several systems [16]. In a series of six different experiments, we evaluated the effects of incubation $\left(16 \mathrm{~h}, 37^{\circ} \mathrm{C}\right)$ of IL-13 $(10 \mathrm{ng} / \mathrm{mL})$ and IL-4 $(10 \mathrm{ng} / \mathrm{mL})$, alone or in combination, and of LPS $(100 \mathrm{ng} / \mathrm{mL})$ on the release of total TSLP and of CXCL8 from HLMs. LPS was a potent stimulus for the release of both TSLP (Figure 2A) and CXCL8 from HLMs (Figure 2B). IL-4, but not IL-13, induced the release of TSLP compared to control. Both IL-4 and IL-13 did not increase the release of CXCL8 from HLMs (Figure 2B). The combination of IL-4 plus IL-13 did not increase the release of TSLP induced by IL-4 (Figure 2A). IL-4 plus IL-13 had no effect on CXCL8 production from HLMs (Figure 2B). In selected experiments, preincubation (30 min, $\left.37^{\circ} \mathrm{C}\right)$ of HLMs with actinomycin D $(1 \mu \mathrm{g} / \mathrm{mL})$, a transcription inhibitor [78], completely blocked LPS- and IL-4-induced TSLP release from HLMs (data not shown), suggesting that these stimuli caused the de novo synthesis of TSLP. 
(A)

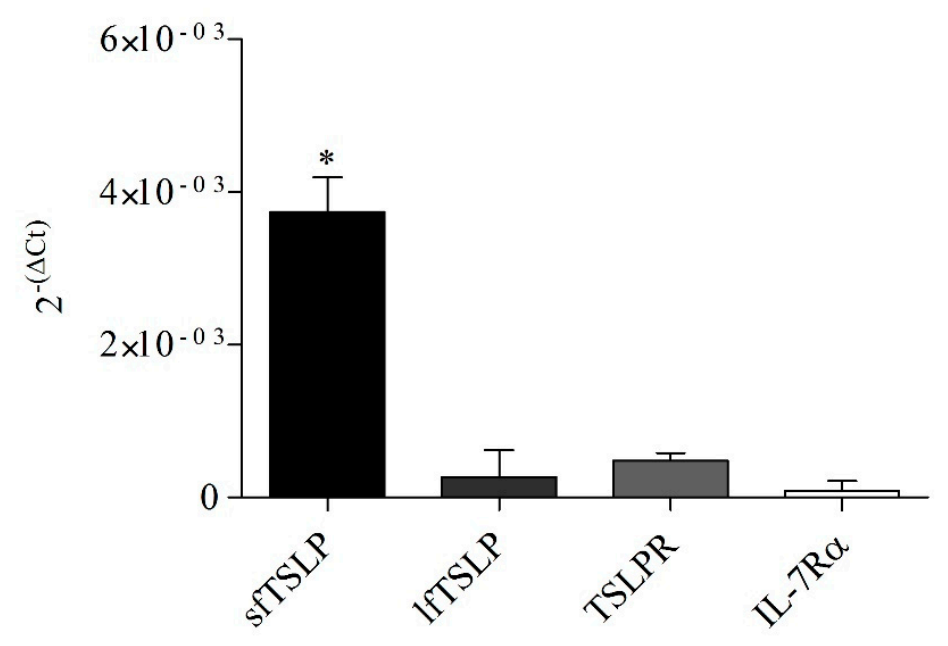

(B)

CTRL

(C)

TSLP
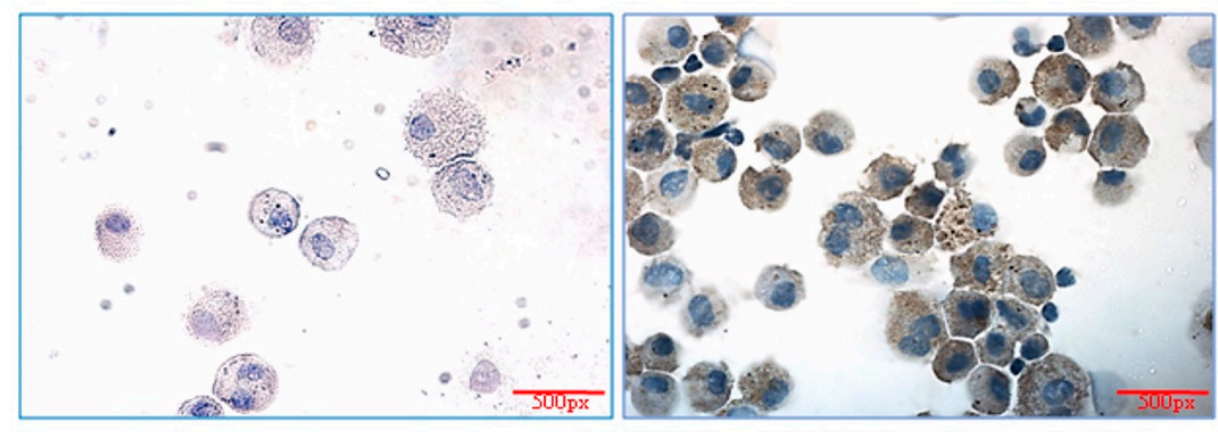

(D)

TSLPR

(E)

IL-7R $\alpha$
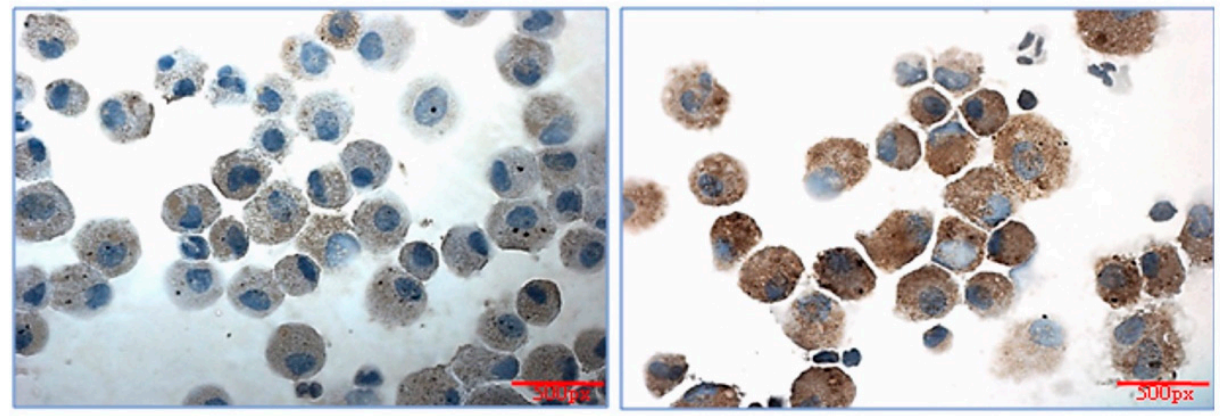

Figure 1. Constitutive expression of TSLP system in human lung macrophages (HLMs). The constitutive expression of sfTSLP, IfTSLP, TSLPR and IL-7R $\alpha$ mRNAs was evaluated by quantitative RT-PCR in highly purified HLMs $\left(4.5 \times 10^{6}\right.$ cells/well) (A). Data are mean \pm SD of 6 independent experiments obtained from different patients. Cytocentrifuge preparations of HLMs were immunohistochemically stained for TSLP (C), TSLPR (D), and IL-7R $\alpha(\mathbf{E})$ with specific primary antibodies or in absence (B) of primary antibody (CTRL) as described in Materials and Methods. Microscope magnification $60 \times$. Results are representative of 6 independent experiments obtained from different patients. ${ }^{*} p<0.01$ when compared to lfTSLP, TSLPR, IL-7R $\alpha$. px: pixels. 
(A)

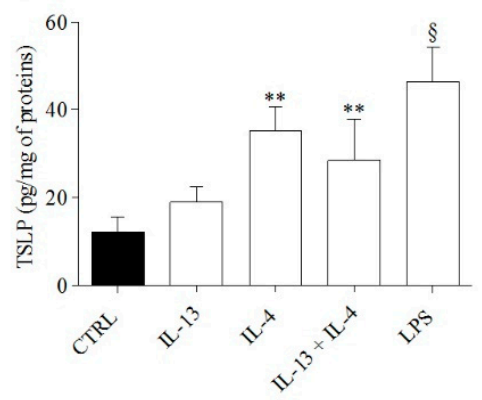

(C)

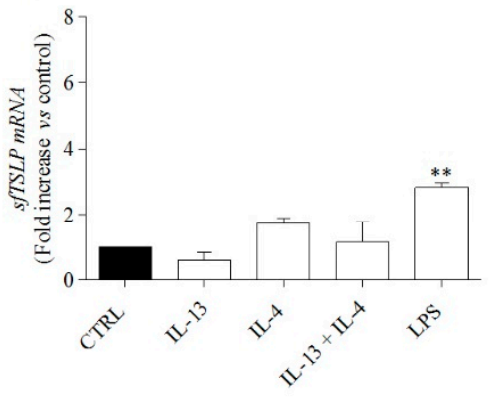

(E)

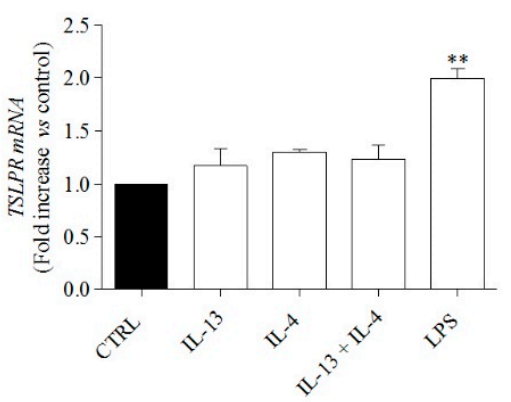

(B)

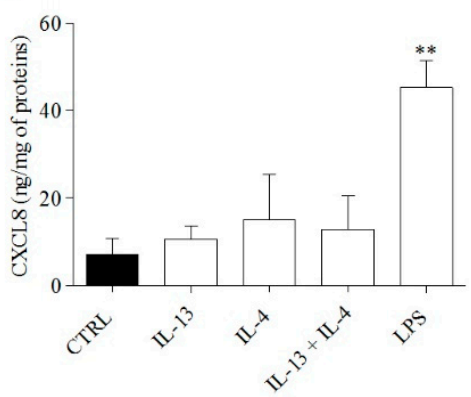

(D)

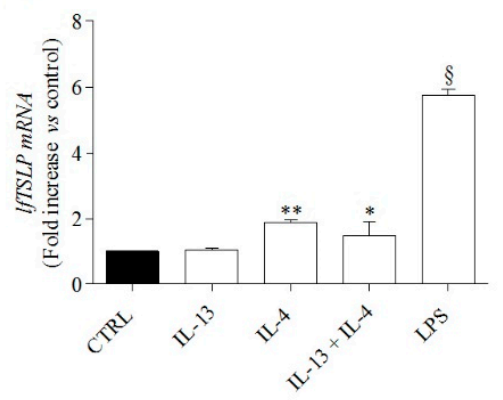

(F)

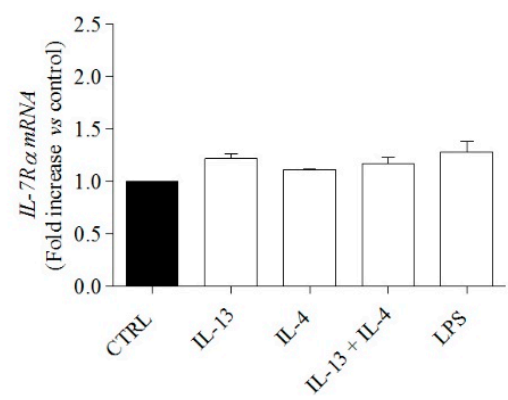

Figure 2. Effects of IL-13 and IL-4, alone or in combination, and of LPS on TSLP system in HLMs. Highly purified HLMs $\left(1.5 \times 10^{5}\right.$ cells/well) were incubated $\left(16 \mathrm{~h}, 37^{\circ} \mathrm{C}\right)$ in the absence (CTRL) or in the presence of IL-13 (10 ng/mL), IL-4 (10 ng/mL) or their combination, or LPS (100 ng/mL (A,B). At the end of incubation, TSLP (A) and CXCL8 (B) proteins in supernatants were evaluated by ELISA. In parallel experiments, $\operatorname{HLM}\left(4.5 \times 10^{6}\right.$ cells / well $)$ were incubated $\left(6 \mathrm{~h}, 37^{\circ} \mathrm{C}\right)$ in the absence $(\mathrm{CTRL})$ or in presence of IL-13 $(10 \mathrm{ng} / \mathrm{mL})$, IL-4 $(10 \mathrm{ng} / \mathrm{mL})$ or their combination, or LPS $(100 \mathrm{ng} / \mathrm{mL})$. At the end of incubation, sfTSLP (C), IfTSLP (D), TSLPR (E), and IL-7R $\alpha$ (F) mRNAs were determined by quantitative RT-PCR. Data are mean \pm SD of 6 independent experiments obtained from different patients. ${ }^{*} p<0.01,{ }^{* *} p<0.001$ and ${ }^{\S} p<0.0001$ vs. CTRL.

We also evaluated the effects of IL-4, IL-13, alone or in combination, and of LPS on TSLP isoforms, TSLPR, and IL-7R $\alpha$ mRNAs in HLMs. LPS markedly increased the proinflammatory lfTSLP mRNA (Figure 2D), and to a lesser extent, sfTSLP mRNA (Figure 2C). IL-13, IL-4, and their combination had no effect of sfTSLP mRNA expression (Figure 2C). By contrast, IL-4, but not IL-13, upregulated lfTSLP mRNA (Figure 2D). The combination of IL-4 plus IL-13 also increased lfTSLP mRNA (Figure 2D). In parallel experiments, LPS upregulated only TSLPR mRNA (Figure 2E) but not IL-7R $\alpha$ while IL-4 and IL-13, alone or in combination, had no effects on TSLPR and IL-7R $\alpha$ (Figure 2E,F). 


\subsection{Effects of IL-4 and IL-13, Alone or in Combination, on Cytokine Release from LPS-Activated HLMs}

We next examined whether IL-4 or IL-13, alone or in combination, modified cytokine production (i.e., TSLP and CXCL8) from LPS-activated HLMs. Figure 3A shows that preincubation $\left(10 \mathrm{~min}, 37^{\circ} \mathrm{C}\right)$ of HLMs with IL-4 $(10 \mathrm{ng} / \mathrm{mL})$, but not IL-13 $(10 \mathrm{ng} / \mathrm{mL})$, before the stimulation with LPS $(100 \mathrm{ng} / \mathrm{mL})$ significantly potentiated TSLP release from HLMs. Although, IL-13 alone had no effect, the combination of IL-4 plus IL-13 further enhanced the production of TSLP from LPS-activated HLMs (Figure 3A). Surprisingly, IL-4 and the combination IL-4 plus IL-13 equally inhibited LPS-induced CXCL8 release from HLMs (Figure 3B). IL-13 alone had no significant effect on the release of CXCL8 from LPS-activated HLMs (Figure 3B).

(A)

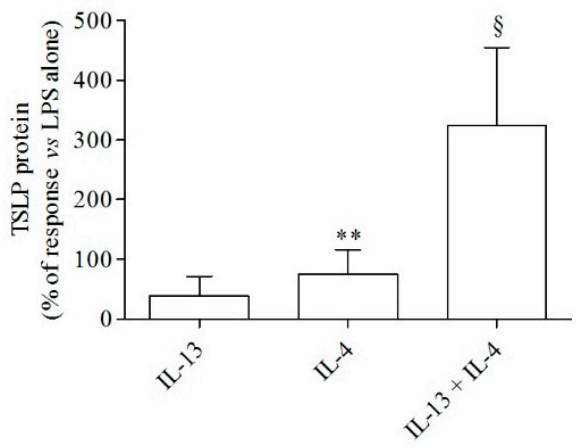

(B)

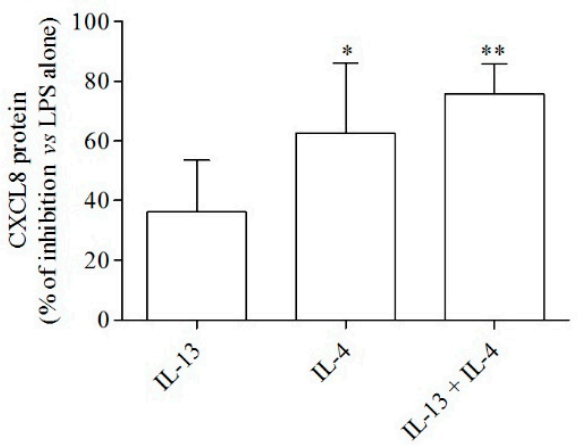

Figure 3. Effects of IL-13 and IL-4, alone or in combination, on TSLP and CXCL8 release from LPS-activated HLMs. Highly purified HLMs $\left(1.5 \times 10^{5}\right.$ cells $/$ well $)$ were preincubated $\left(10 \mathrm{~min}, 37^{\circ} \mathrm{C}\right)$ with IL-13 (10 ng/mL) or IL-4 $(10 \mathrm{ng} / \mathrm{mL})$, alone or in combination, before the stimulation with LPS $(100 \mathrm{ng} / \mathrm{mL})$. TSLP (A) and CXCL8 (B) proteins in supernatants were evaluated by ELISA. Data are mean \pm SD of 6 independent experiments obtained from different patients. ${ }^{*} p<0.01,{ }^{* *} p<0.001$ and ${ }^{\S} p<0.0001$ vs. LPS alone.

\subsection{TSLP System in Monocytes and Monocyte Macrophage-Derived (MDMs)}

We also assessed the expression of TSLP system in another model of human macrophages such as monocyte-derived macrophages (MDMs) and on their precursors, the peripheral blood monocytes [59]. MDMs (Figure 4A) and freshly isolated monocytes (Figure 4B) constitutively expressed sfTSLP mRNA. IfTSLP, TSLPR, and IL-7R $\alpha$ mRNAs were essentially undetectable in both MDMs and monocytes. Figure $4 \mathrm{C}$ shows that peripheral blood monocytes and MDMs contained immunoreactive total TSLP protein evaluated by ELISA.

We next evaluated the effects of IL-4 $(10 \mathrm{ng} / \mathrm{mL})$ and IL-13 $(10 \mathrm{ng} / \mathrm{mL})$, alone or in combination, and of LPS (100 ng/mL), on TSLP system in MDMs and monocytes. Similarly to HLMs, both LPS and IL-4 induced the release of TSLP from both MDMs (Figure 5A) and monocytes (Figure 5B), whereas IL-13 had no effect. Preincubation $\left(10 \mathrm{~min}, 37^{\circ} \mathrm{C}\right)$ of MDMs and monocytes with IL-4, but not IL-13, enhanced TSLP production from LPS-activated MDMs (Figure 5C) and monocytes (Figure 5D). The combination of two cytokines, IL-4 plus IL-13, did not enhance the activating property of IL-4 on MDMs (Figure 5C) and on peripheral blood monocytes (Figure 5D). 


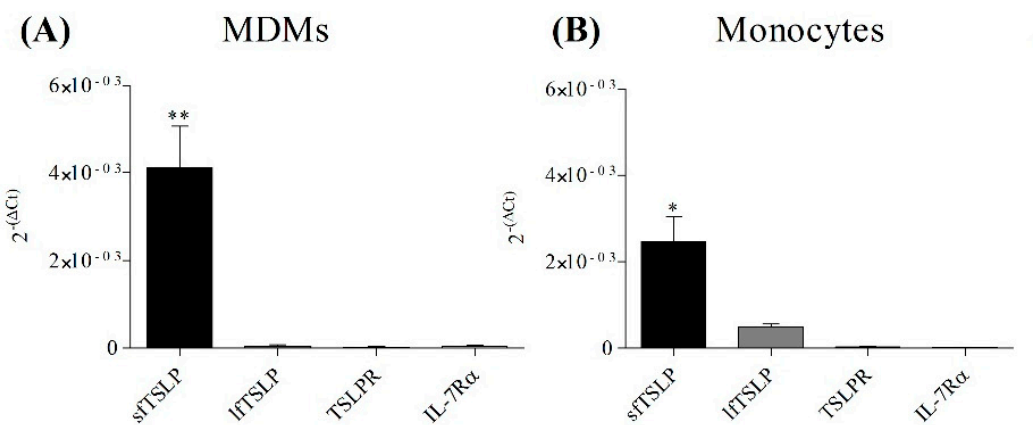

(C)

Figure 4. Constitutive expression of sfTSLP, lfTSLP, TSLPR, and IL-7R $\alpha$ mRNAs and intracellular concentration of TSLP protein in MDMs and monocytes. MDMs $\left(4.5 \times 10^{6}\right.$ cells $/$ well $)(A)$ and freshly purified monocytes $\left(4.5 \times 10^{6}\right.$ cells $/$ well $)($ B $)$ were lysed with RNA lysis buffer to evaluate the expression of sfTSLP, IfTSLP, TSLPR and IL-7R $\alpha$ mRNAs by quantitative RT-PCR (A,B). Total TSLP intracellular concentrations in MDMs and monocytes were evaluated by ELISA (C). Data are mean \pm SD of 6 independent experiments obtained from different healthy donors. ${ }^{*} p<0.05$ when compared to lfTSLP, TSLPR, IL-7R $\alpha .{ }^{* *} p<0.01$ when compared to lfTSLP, TSLPR, IL-7R $\alpha$.

(A)

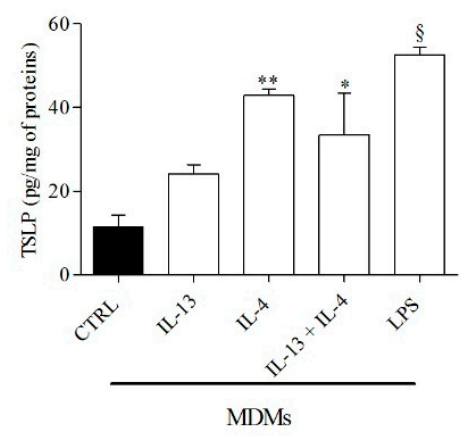

(C)

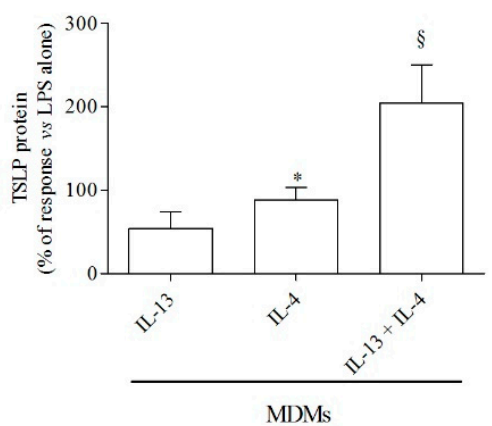

(B)

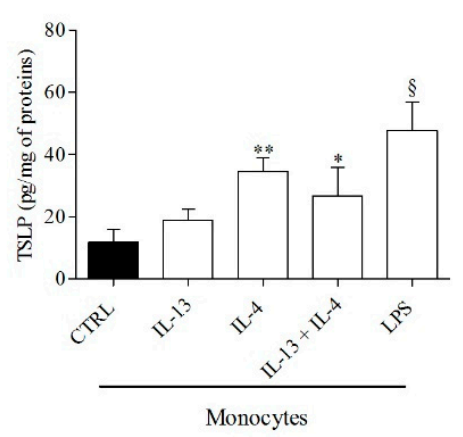

(D)

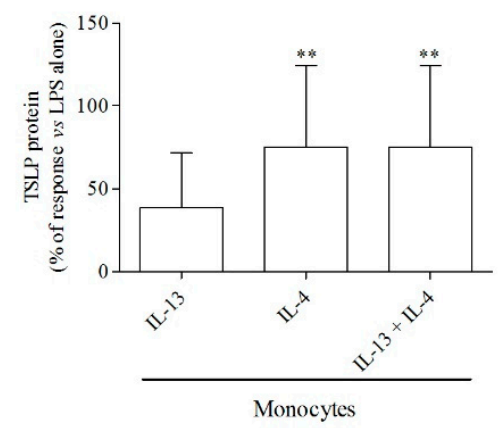

Figure 5. Effects of IL-13, IL-4, alone or in combination, and of LPS on TSLP production by MDMs and monocytes. MDMs $\left(1.5 \times 10^{5}\right.$ cells/well $)(\mathbf{A})$ and monocytes $\left(1.5 \times 10^{5}\right.$ cells $/$ well $)(\mathbf{B})$ were incubated $\left(16 \mathrm{~h}, 37^{\circ} \mathrm{C}\right)$ in the presence of IL-13 $(10 \mathrm{ng} / \mathrm{mL}), \mathrm{IL}-4(10 \mathrm{ng} / \mathrm{mL})$, alone or in combination, or LPS $(100 \mathrm{ng} / \mathrm{mL})$. In parallel experiments, MDMs $\left(1.5 \times 10^{5}\right.$ cells/well) $(\mathrm{C})$ and monocytes $\left(1.5 \times 10^{5}\right.$ cells $/$ well $)(D)$ were preincubated $\left(10 \mathrm{~min}, 37^{\circ} \mathrm{C}\right)$ with IL-13 $(10 \mathrm{ng} / \mathrm{mL})$ or IL-4 $(10 \mathrm{ng} / \mathrm{mL})$, alone or in combination, before the stimulation with LPS (100 $\mathrm{ng} / \mathrm{mL})$. Incubation continued for $16 \mathrm{~h}$ at $37^{\circ} \mathrm{C}$. In both groups of experiments, at the end of incubations TSLP concentrations in supernatants were evaluated by ELISA. Data are mean \pm SD of 6 independent experiments obtained from different healthy donors. ${ }^{*} p<0.01$, ${ }^{* *} p<0.001$ and ${ }^{\S} p<0.0001$ vs. CTRL (A,B) and vs. LPS (C,D).

\subsection{Effects of TSLP on the Release of Angiogenic and Lymphangiogenic Factors from HLMs}

Our results show that HLMs constitutively express the TSLP receptors and contain TSLP, which can be immunologically released. These results prompted us to investigate 
whether HLMs could be a target of TSLP. Therefore, in four independent experiments, we assessed the effects of TSLP on the release of inflammatory, angiogenic, and lymphangiogenic mediators from HLMs. Figure 6 shows that incubation $\left(24 \mathrm{~h}, 37^{\circ} \mathrm{C}\right)$ of HLMs with TSLP $(5 \mathrm{ng} / \mathrm{mL})$ induced the release of proinflammatory TNF- $\alpha$ (Figure $6 \mathrm{~A}$ ), angiogenic (VEGF-A and ANGPT2) (Figure 6B,C), and lymphangiogenic (VEGF-C) mediators (Figure 6D). The release of TNF- $\alpha$, VEGF-C and ANGPT2 induced by TSLP was mediated by the activation of gene transcription (Figure $6 \mathrm{E}, \mathrm{G}, \mathrm{H}$ ). Interestingly, TSLP did not induce the expression for VEGF-A mRNA (Figure 6H), suggesting that VEGF-A is released from intracellular stores.

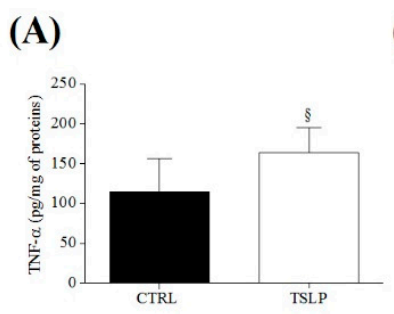

(E)

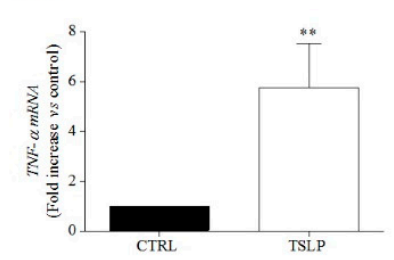

(B)

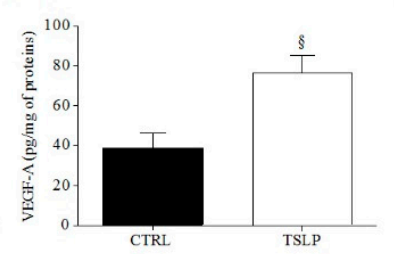

(F)

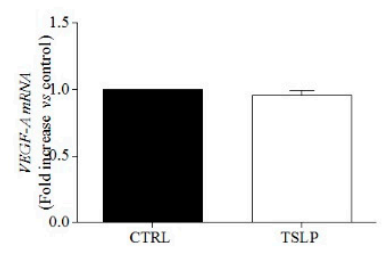

(C)

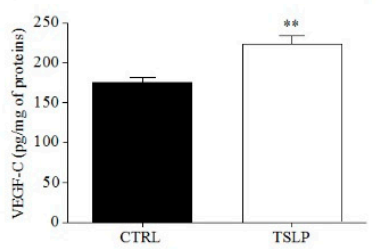

(G)

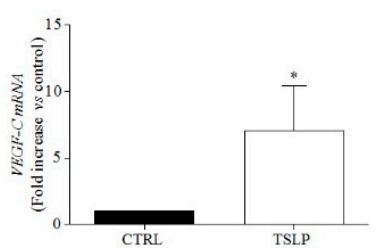

(D)

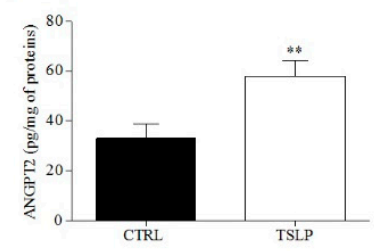

(H)

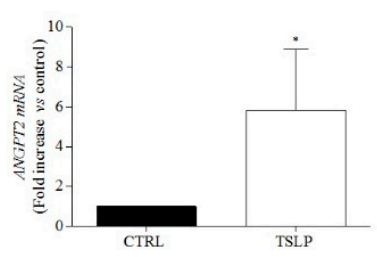

Figure 6. Effects of TSLP on the release and expression of inflammatory, angiogenic and lymphangiogenic mediators from HLMs. HLMs $\left(1.5 \times 10^{5}\right.$ cells/well) were incubated $\left(16 \mathrm{~h}, 37^{\circ} \mathrm{C}\right)$ in the absence $(\mathrm{CTRL})$ or in the presence of TSLP $(5 \mathrm{ng} / \mathrm{mL})$. At the end of the incubation, TNF- $\alpha(\mathbf{A})$, VEGF-A (B), VEGF-C (C) and ANGPT2 (D), and concentrations in the supernatants were evaluated by ELISA. In parallel experiments, HLMs $\left(4.5 \times 10^{5}\right.$ cells $/$ well $)$ were incubated $\left(6 \mathrm{~h}, 37^{\circ} \mathrm{C}\right)$ in the absence (CTRL) or in the presence of TSLP $(5 \mathrm{ng} / \mathrm{mL})$. TNF- $\alpha(\mathbf{E})$, VEGF-A (F), VEGF-C (G), and ANGPT2 (H) mRNAs were determined by quantitative RT-PRC. Data are mean \pm SD of 4 independent experiments obtained from different patients. ${ }^{\S} p<0.0001$ vs. control (CTRL). ${ }^{*} p<0.05$ vs. control; ${ }^{* *} p<0.01$ vs. control (CTRL).

\subsection{Expression of TSLP System in Peritumoral and Intratumoral Human Lung Cancer}

TSLP is a pleiotropic cytokine that has been implicated in a variety of immune disorders, including different solid and hematologic tumors [2]. The role of TSLP in cancer is rather controversial [2], although in the majority of tumors it plays a protumorigenic role $[33,41,44,45]$. We evaluated the expression of TSLP, TSLPR, and IL-7R $\alpha$ by immunohistochemistry in peritumoral and intratumoral areas of human lung cancer (Figure 7). The results of a typical experiment showed that the expression of TSLP, TSLPR and IL-7R $\alpha$ was higher in the intratumoral area compared to peritumoral area of lung cancer. Similar results were obtained in five independent experiments.

To confirm and extend the previous observation, we evaluated the expression of sfTSLP, IfTSLP, TSLPR, and IL-7R $\alpha$ mRNAs in intratumoral and peritumoral areas of human lung cancer. In a series of five different experiments, the anti-inflammatory sfTSLP mRNA was significantly more expressed in the intratumoral area compared to the peritumoral region. The proinflammatory lfTSLP mRNA isoform was highly present in both peritumoral and intratumoral tissues, but significantly more expressed in peritumoral section (Figure 8A). TSLPR mRNA was equally distributed in peri- and intratumoral areas (Figure $8 \mathrm{~A}, \mathrm{~B}$ ), whereas IL-7R $\alpha$ mRNA was detected only in intratumoral lung tissue (Figure $8 \mathrm{~B})$. The concentration of immunoreative total TSLP protein was higher in intratumoral lung cancer compared to peritumoral tissue (Figure $8 \mathrm{C}$ ). 


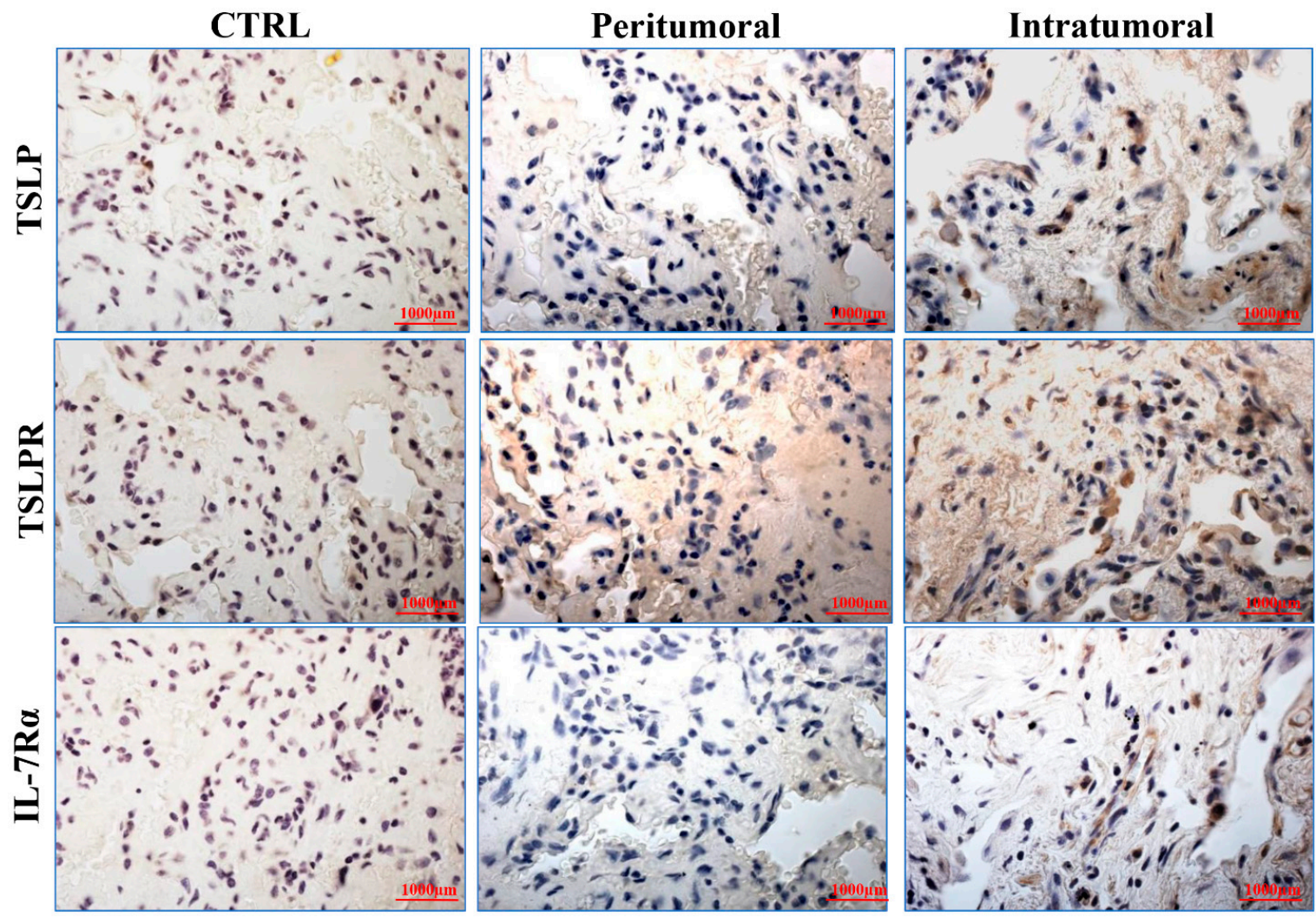

Figure 7. Expression of TSLP, TSLPR, and IL-7R $\alpha$ in peritumoral and intratumoral human lung cancer by immunohistochemistry. Immunohistochemical staining for TSLP, TSLPR, and IL-7R $\alpha$ in peritumoral and intratumoral human lung cancer. In the control (CTRL), the primary antibody was omitted. Microscope magnification $20 \times$. This experiment is representative of 5 experiments obtained from different patients.

(A)

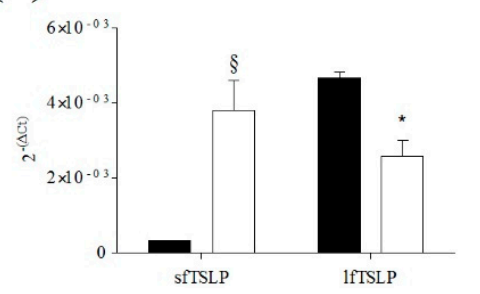

(C)

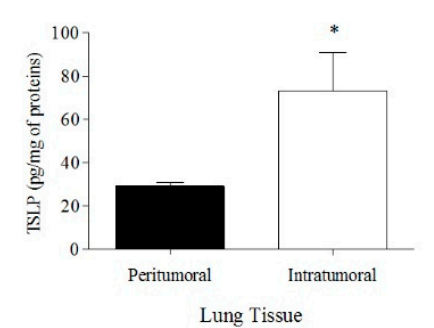

(B)

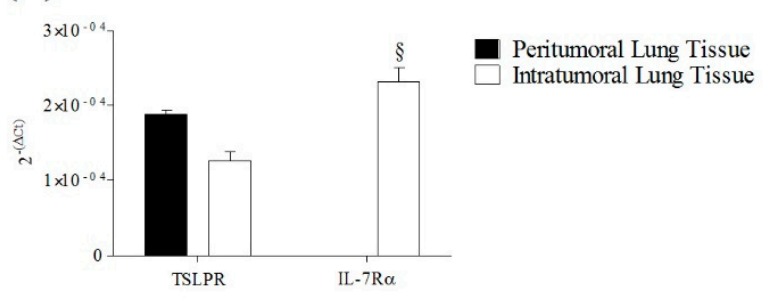

Figure 8. Expression of sfTSLP, lfTSLP, TSLPR, and IL-7R $\alpha$ mRNAs in peritumoral and intratumoral human lung tissues. Peritumoral and intratumoral human lung tissues ( $2 \mathrm{mg}$ ) disrupted by homogenization were lysed and $500 \mu \mathrm{L}$ of $0.1 \%$ Triton X-100. sfTSLP and lfTSLP mRNAs were determined by quantitative RT-PCR (A,B). Total TSLP was evaluated in lysed peritumoral and intratumoral lung cancer tissue by ELISA (C). Data are mean \pm SD of 5 independent experiments obtained from different patients. ${ }^{*} p<0.01$ and ${ }^{\S} p<0.0001$ vs. peritumoral lung tissue. 


\section{Discussion}

In the present study, we have demonstrated that the TSLP system is constitutively expressed in macrophages purified from lung tissue of patients with lung cancer in monocytederived macrophages (MDMs) and in peripheral blood monocytes obtained from normal donors. HLMs, MDMs, and monocytes constitutively expressed the anti-inflammatory sfTSLP mRNA and contained immunoreative total TSLP protein. Incubation of HLMs with TSLP induced the release of proinflammatory (TNF- $\alpha$ ), angiogenic (VEGF-A and ANGPT2), and lymphangiogenic (VEGF-C) factors. sfTSLP and lfTSLP were differentially expressed in peritumoral and intratumoral human lung cancer tissues.

LPS was found a potent stimulus for the release of total TSLP protein from HLMs. TSLP activated the cells by binding to a heterodimeric complex composed of TSLPR and IL-7R $\alpha$. LPS induced an increase of gene expression of TSLPR from HLMs, but had no effect on IL-7R $\alpha$ expression. Interestingly, canonical $\mathrm{T}_{\mathrm{H}}$ 2-like cytokines, IL-4 and IL-13, differently modulated the release of TSLP from HLMs. While IL-4 was a potent stimulus for the release of TSLP from HLMs, IL-13 alone was essentially ineffective. Moreover, the combination of IL-4 plus IL-13 did not increase the activating property of IL-4. These observations are rather interesting for several reasons. First, they suggest that IL-4 plays a modulatory role on the release of TSLP from primary lung macrophages. These cells are primarily involved in the pathogenesis of several lung inflammatory disorders [79], including COPD [80], and lung cancer [81-83]. Therefore, the interaction between IL-4 and TSLP could contribute to the development of these lung disorders.

IL-4, but not IL-13, synergistically potentiated the release of total TSLP protein induced by LPS from HLMs. The latter observation extends previous results demonstrating that IL-4 synergistically enhanced the production of TSLP induced by dsDNA from airway epithelial cells [4]. Similarly, IL-4 synergized with LPS in the expression and production of TSLP from dendritic cells (DCs) [16].

It is well established that low-grade inflammation plays a role in the switch between dormancy and proliferation of metastatic cells $[84,85]$. LPS nasal instillation in mice bearing dormant cancer cells caused awakening of tumor cells and cancer progression [86]. On the other side, tumors displaying a $\mathrm{T}_{\mathrm{H}} 2$ signature have a worse prognosis than that of tumors with $\mathrm{T}_{\mathrm{H}} 1$ predominant response $[33,87]$. De Monte and collaborators have demonstrated in human pancreatic cancer that TSLP drives the differentiation of $\mathrm{T}_{\mathrm{H}} 2$ cells and is associated with a worse prognosis [33]. Our results showing a synergistic interaction between IL-4 and LPS on the release of TSLP from human lung macrophages might have translational relevance in the context of lung cancer.

It is presently unclear why IL-13, which shares many $[88,89]$ but not all immunological and biological effects with IL-4 [90,91], did not induce the release of TSLP from HLMs and did not potentiate the activating property of LPS. IL- 4 and IL-13 are encoded by adjacent genes that share many cis-acting and trans-activating regulatory elements, and they signal through a partially shared receptor and adaptor system [92,93]. In particular, IL-4 activates the type I (IL-4R $\alpha$ and $\gamma$ c) and type II (IL-4R $\alpha$ and IL-13R $\alpha 1$ ) receptors, whereas IL-13 binds only to IL-13R $\alpha 1$ chain of type II receptor and to the single chain receptor IL$13 R \alpha 2[88,90,91,94]$. In addition, epigenetic and functional studies have suggested unique and non-redundant roles for these cytokines in vivo and in vitro studies [95-97]. Therefore, it is not surprising that the two cytokines exert distinct effects in certain immune cells [88]. Differences between IL-4 and IL-13 have been reported on the mouse macrophages responsiveness to TSLP [98]. Whatever the interpretation of these results, given the relevance of TSLP [99-104] and $\mathrm{T}_{\mathrm{H}} 2$ cytokines in the pathogenesis of asthma [105,106], it is likely that these observations have translational relevance contributing to clinical manifestations of chronic inflammatory lung disorders.

Another unexpected finding of our study was the specificity of the synergistic interaction between IL-4 and LPS on the production of TSLP from HLMs. To our surprise, we found that IL-13 inhibited the release of CXCL8 from LPS-activated HLMs. Also in these experiments the modulating effect of IL-4 diverged from that of IL-13. Moreover, 
the combination of IL-4 plus IL-13 did not enhance the inhibitory effect of IL-4 on CXCL8 release from lung macrophages. The opposing effects of IL-13 and of IL- 4 on the release of TSLP and CXCL8 from LPS-activated HLMs are intriguing but difficult to explain and deserve further studies.

Peripheral blood monocytes and tissue macrophages represent two distinct branches of the mononuclear system [52]. MDMs are derived from monocytes differentiated to macrophages in the presence of G-CSF [59]. We have previously reported some biological and immunological differences between primary HLMs and MDMs [59]. In this study, HLMs, MDMs and peripheral blood monocytes contained immunoreactive TSLP and constitutively expressed sfTSLP mRNA. In addition, in HLMs, MDMs and monocytes IL-4, but not IL-13, and LPS induced the expression of sfTSLP mRNA and the release of total TSLP. Peripheral blood monocytes and MDMs show some similarities with HLMs purified from lung cancer with respect to the TSLP system. However, a better comparison of the TSLP system should be performed among peripheral blood monocytes, MDMs and HLMs obtained from the same lung cancer patients. Collectively, these results emphasize the relevance of TSLP system in the human mononuclear phagocyte system.

The production of TSLP by HLMs suggested to us possible autocrine effects on these cells which are the most representative immune cells in human lung parenchyma [71,107]. We found that HLMs incubated with TSLP released significant amount of proinflammatory TNF- $\alpha$ and of several angiogenic (i.e., VEGF-A and ANGPT2) [108,109] and lymphangiogenic molecules (i.e., VEGF-C) [110,111]. These findings were supported by the observation that TSLP markedly increased the expression of TNF- $\alpha$, VEGF-C, ANGPT2 mRNAs. VEGFA mRNA was not induced by TSLP, suggesting that this angiogenic factor is contained in HLMs [75]. It has been previously shown that TSLP derived from human and mouse tumors induced VEGF-A release from alveolar macrophages and enhanced metastasis formation [30]. The release of angiogenic and lymphangiogenic mediators from TSLPactivated macrophages might explain, at least in part, the protumorigenic role in TSLP in several human cancers $[31,33,35,40,41,44,45]$.

All the previously mentioned mediators play pivotal roles in tumor initiation and progression, tumor angiogenesis, and the formation of metastasis $[109,112]$. These results prompted us to investigate the expression of TSLP system in human lung cancer. Our results provide evidence, to our knowledge for the first time, that TSLP isoforms, TSLPR, and IL-7R $\alpha$ were expressed in both intratumoral and peritumoral lung cancer tissues. The concentration of total TSLP protein was higher in the intratumoral area compared to peritumoral tissue. Interestingly, the proinflammatory lfTSLP mRNA isoform was highly expressed in peritumoral microenvironment of human lung cancer. The latter findings extend previous observations demonstrating that cancer cells can release TSLP $[31,44,45]$ and that tumor cells can express TSLPR and IL-7R $\alpha$ [31]. Interestingly, the anti-inflammatory and homeostatic sfTSLP was more expressed in intratumoral tissue compared to peritumoral area.

The expression of total TSLP protein has been previously described in human lung carcinoma [46]. TSLP was overexpressed intratumorally compared to peritumoral lung cancer tissue and benign lesions. Interestingly, the number of Foxp $3^{+}$Tregs in lung cancer tissue was significantly increased compared to peritumoral lung tissue. Finally, the authors found that TSLP activated dendritic cells favoring the differentiation and migration of $\mathrm{CD}^{+} \mathrm{CD}^{+} 5^{+}$Treg cells. It is well established that Treg cells are increased in tumor microenvironment [113,114]. Collectively, these results highlight a novel mechanism by which TSLP, produced by tumor and immune cells (e.g., macrophages), might amplify an immunosuppressive microenvironment in lung cancer.

The role of TSLP in cancer is still controversial [2,115]. Although the majority of experimental [29-32] and human studies [33-46] have demonstrated a protumorigenic role for TSLP, few groups have reported a tumor-suppressing role for TLSP in experimental [47-51] and human cancer [48]. These apparently contrasting results could be explained by the use of different experimental models, different types and stages of cancer, and many other reasons. We would like to suggest that the two isoforms of TSLP (lf and sfTSLP), exerting 
opposing effects on various aspects of inflammation $[1,13,14,116]$, could contribute, at least in part, to explain some of these contrasting results. Further studies on the roles of TSLP isoforms and their localization in peritumoral and intratumoral areas of tumors could help clarify the TSLP role in different cancers.

TSLP is an upstream cytokine primarily released by airway epithelial cells in response to a variety of environmental stimuli [1,117], initiating a range of downstream inflammatory pathways [117]. In patients with asthma, TSLP drives a T2 lung inflammatory response [18,116], but it is also involved in non-T2 processes [117]. Our results indicate that the $\mathrm{T}_{\mathrm{H}} 2$ cytokine IL-4 selectively induced the release of total TSLP from HLMs. In addition, IL-4 and the combination of IL-4 plus IL-13 enhanced TSLP release from LPS-activated HLMs. The interaction between a non-IgE-mediated stimulus, such as LPS, $\mathrm{T}_{\mathrm{H}} 2$ cytokines and TSLP in human lung macrophages greatly extend the potential proinflammatory roles of TSLP in inflammatory lung disorders. The relevance of TSLP-dependent $\mathrm{T}_{\mathrm{H}} 2$ inflammation in allergic disorders and in cancer has been recently emphasized [2,28].

This study has several limitations that should be pointed out. The in vitro experiments were performed using primary macrophages obtained from lung parenchyma of patients with lung adenocarcinoma. The possibility that the underlying disease may have affected some of our results cannot be dismissed. HLMs, obtained from lung tissue, are in close proximity to cancer cells. The in vivo exposure to tumor microenvironment may have affected the expression of TSLP system and the functional activity of lung macrophages. Moreover, recent studies have highlighted the extraordinary heterogeneity of human lung macrophages $[54,70,79]$. Our experiments were performed using highly purified macrophages obtained from mechanically dispersed lung parenchyma. We cannot exclude the possibility that different clusters of human lung macrophages selectively express TSLP receptor and/or preferentially express sfTSLP and IfTSLP. Similarly, three subsets of human monocytes (classical, intermediate, and non-classical) have been phenotypically identified [118]. We have provided preliminary evidence of the differential expression of TSLPR in functionally discrete subsets of human monocyte [76]. Finally, there is compelling evidence of the dichotomy of two isoforms of TSLP (sf and lfTSLP) in different pathophysiological conditions $[13,14,119]$. In this study we measured total TSLP by ELISA because specific antibodies to identify the two isoforms are not yet available. However, we identified the two TSLP isoforms in HLMs, MDMs and monocytes, and in human lung cancer tissue. Future studies should go deeper inside the biochemical and immunological mechanisms of formation of different TSLP isoforms and their multifaceted roles in cancer and in chronic inflammatory disorders.

\section{Conclusions}

In conclusion, primary human lung macrophages, MDMs, and peripheral blood monocytes express the homeostatic sfTSLP, TSLPR, and IL-7R $\alpha$ and contain immunoreactive total TSLP protein. LPS and IL-4, alone or in combination, lead to an increase of lfTSLP mRNA expression and the release of TSLP from HLMs and MDMs. TSLP induces the release of several angiogenic and lymphangiogenic factors from HLMs. TSLP protein and TSLP isoforms are found in intratumoral and peritumoral human lung cancer. Collectively, our results indicate that the TSLP system, widely expressed throughout the human mononuclear system, could be involved in chronic inflammatory disorders and lung cancer.

Author Contributions: Conceptualization, M.B., M.R.G., G.M., G.V. and S.L.; methodology, M.B., D.S. and R.M.D.C.; investigation, M.B., A.F., D.S., M.R.G., M.S., G.V. and S.L.; data curation, M.B., D.S., G.V. and S.L.; writing-original draft preparation, M.B. and S.L.; writing-review and editing, G.M., G.V. and S.L.; supervision, S.L.; funding acquisition, M.R.G., G.M., G.V. and S.L. All authors have read and agreed to the published version of the manuscript.

Funding: This work was supported in part by grants from the CISI-Lab Project (University of Naples Federico II), TIMING Project and Campania Bioscience (Regione Campania) (G.V., S.L.), and by MIUR PRIN 2017 M8Y MR8_005 and AIRC_MFAG 2020 (ID. project 25123) (M.R.G.). 
Institutional Review Board Statement: The study was conducted according to the guidelines of the Declaration of Helsinki and approved by the Ethics Committee of University of Naples Federico II (Prot. 7/19).

Informed Consent Statement: Informed consent was obtained from all donors involved in the study and written informed consent for publication was obtained from participants.

Data Availability Statement: Data supporting the reported results are available upon request.

Acknowledgments: We would like to thank the administrative staff (Roberto Bifulco and Anna Ferraro), without whom it would not be possible to work as a team.

Conflicts of Interest: The authors declare no conflict of interest.

$\begin{array}{ll}\text { Abbreviations } \\ \text { CAF } & \begin{array}{l}\text { cancer-associated fibroblast } \\ \text { dendritic cell }\end{array} \\ \text { FC } & \text { fetal calf serum } \\ \text { HBsAg } & \text { hepatitis B surface Ag } \\ \text { HLM } & \text { human lung macrophage } \\ \text { IL } & \text { interleukin } \\ \text { IL-7R } \alpha & \text { interleukin-7 receptor } \alpha \\ \text { IfTSLP } & \text { long form TSLP } \\ \text { LPS } & \text { lipopolysaccharide } \\ \text { MDM } & \text { monocyte-derived macrophage } \\ \text { PAP } & \text { peroxidase anti-peroxidase } \\ \text { PBMC } & \text { peripheral blood mononuclear cell } \\ \text { RT-PCR } & \text { quantitative reverse transcriptase PCR } \\ \text { sfTSLP } & \text { short form TSLP } \\ \text { TH2 } & \text { T helper } 2 \\ \text { TSLP } & \text { thymic stromal lymphopoietin } \\ \text { TSLPR } & \text { thymic stromal lymphopoietin receptor } \\ \text { VEGF } & \text { vascular endothelial growth factor }\end{array}$

\section{References}

1. Varricchi, G.; Pecoraro, A.; Marone, G.; Criscuolo, G.; Spadaro, G.; Genovese, A. Thymic Stromal Lymphopoietin Isoforms, Inflammatory Disorders, and Cancer. Front. Immunol. 2018, 9, 1595. [CrossRef]

2. Corren, J.; Ziegler, S.F. Tslp: From Allergy to Cancer. Nat. Immunol. 2019, 20, 1603-1609. [CrossRef]

3. Allakhverdi, Z.; Comeau, M.R.; Jessup, H.K.; Delespesse, G. Thymic Stromal Lymphopoietin as a Mediator of Crosstalk between Bronchial Smooth Muscles and Mast Cells. J. Allergy Clin. Immunol. 2009, 123, 958-960 e2. [CrossRef] [PubMed]

4. Kato, A.; Favoreto, S., Jr.; Avila, P.C.; Schleimer, R.P. Tlr3- and Th2 Cytokine-Dependent Production of Thymic Stromal Lymphopoietin in Human Airway Epithelial Cells. J. Immunol. 2007, 179, 1080-1087. [CrossRef] [PubMed]

5. Lee, C.H.; Ziegler, S.F. Inducible Expression of the Proallergic Cytokine Thymic Stromal Lymphopoietin in Airway Epithelial Cells Is Controlled by Nfkappab. Proc. Natl. Acad. Sci. USA 2007, 104, 914-919. [CrossRef]

6. Calven, J.; Yudina, Y.; Hallgren, O.; Westergren-Thorsson, G.; Davies, D.E.; Brandelius, A.; Uller, L. Viral Stimuli Trigger Exaggerated Thymic Stromal Lymphopoietin Expression by Chronic Obstructive Pulmonary Disease Epithelium: Role of Endosomal Tlr3 and Cytosolic Rig-I-Like Helicases. J. Innate Immun. 2012, 4, 86-99. [CrossRef] [PubMed]

7. Lee, C.H.; Headley, M.B.; Loo, Y.M.; Berlin, A.; Gale, M., Jr.; Debley, J.S.; Lukacs, N.W.; Ziegler, S.F. Thymic Stromal Lymphopoietin Is Induced by Respiratory Syncytial Virus-Infected Airway Epithelial Cells and Promotes a Type 2 Response to Infection. J. Allergy Clin. Immunol. 2012, 130, 1187-1196 e5. [CrossRef]

8. Nagarkar, R.D.; Poposki, J.A.; Comeau, M.R.; Biyasheva, A.; Avila, P.C.; Schleimer, R.P.; Kato, A. Airway Epithelial Cells Activate Th2 Cytokine Production in Mast Cells through Il-1 and Thymic Stromal Lymphopoietin. J. Allergy Clin. Immunol. 2012, 130, 225-232 e4. [CrossRef]

9. Harada, M.; Hirota, T.; Jodo, A.I.; Doi, S.; Kameda, M.; Fujita, K.; Miyatake, A.; Enomoto, T.; Noguchi, E.; Yoshihara, S.; et al. Functional Analysis of the Thymic Stromal Lymphopoietin Variants in Human Bronchial Epithelial Cells. Am. J. Respir. Cell Mol. Biol. 2009, 40, 368-374. [CrossRef]

10. Iliev, D.I.; Spadoni, I.; Mileti, E.; Matteoli, G.; Sonzogni, A.; Sampietro, G.M.; Foschi, D.; Caprioli, F.; Viale, G.; Rescigno, M. Human Intestinal Epithelial Cells Promote the Differentiation of Tolerogenic Dendritic Cells. Gut 2009, 58, 1481-1489. [CrossRef] 
11. Cultrone, A.; de Wouters, T.; Lakhdari, O.; Kelly, D.; Mulder, I.; Logan, E.; Lapaque, N.; Dore, J.; Blottiere, H.M. The Nf-Kappab Binding Site Located in the Proximal Region of the Tslp Promoter Is Critical for Tslp Modulation in Human Intestinal Epithelial Cells. Eur. J. Immunol. 2013, 43, 1053-1062. [CrossRef] [PubMed]

12. Collison, M.A.; Sokulsky, L.A.; Sherrill, J.D.; Nightingale, S.; Hatchwell, L.; Talley, N.J.; Walker, M.M.; Rothenberg, M.E.; Mattes, J. Tnf-Related Apoptosis-Inducing Ligand (Trail) Regulates Midline-1, Thymic Stromal Lymphopoietin, Inflammation, and Remodeling in Experimental Eosinophilic Esophagitis. J. Allergy Clin. Immunol. 2015, 136, 971-982. [CrossRef] [PubMed]

13. Fornasa, G.; Tsilingiri, K.; Caprioli, F.; Botti, F.; Mapelli, M.; Meller, S.; Kislat, A.; Homey, B.; di Sabatino, A.; Sonzogni, A.; et al. Dichotomy of Short and Long Thymic Stromal Lymphopoietin Isoforms in Inflammatory Disorders of the Bowel and Skin. J. Allergy Clin. Immunol. 2015, 136, 413-422. [CrossRef]

14. Biancheri, P.; di Sabatino, A.; Rescigno, M.; Giuffrida, P.; Fornasa, G.; Tsilingiri, K.; Pender, S.L.; Papadia, C.; Wood, E.; Pasini, A.; et al. Abnormal Thymic Stromal Lymphopoietin Expression in the Duodenal Mucosa of Patients with Coeliac Disease. Gut 2016, 65, 1670-1680. [CrossRef] [PubMed]

15. Gudbjartsson, F.D.; Bjornsdottir, U.S.; Halapi, E.; Helgadottir, A.; Sulem, P.; Jonsdottir, G.M.; Thorleifsson, G.; Helgadottir, H.; Steinthorsdottir, V.; Stefansson, H.; et al. Sequence Variants Affecting Eosinophil Numbers Associate with Asthma and Myocardial Infarction. Nat. Genet. 2009, 41, 342-347. [CrossRef] [PubMed]

16. Kashyap, M.; Rochman, Y.; Spolski, R.; Samsel, L.; Leonard, W.J. Thymic Stromal Lymphopoietin Is Produced by Dendritic Cells. J. Immunol. 2011, 187, 1207-1211. [CrossRef] [PubMed]

17. Soumelis, V.; Reche, P.A.; Kanzler, H.; Yuan, W.; Edward, G.; Homey, B.; Gilliet, M.; Ho, S.; Antonenko, S.; Lauerma, A.; et al. Human Epithelial Cells Trigger Dendritic Cell Mediated Allergic Inflammation by Producing Tslp. Nat. Immunol. 2002, 3, 673-780. [CrossRef] [PubMed]

18. Allakhverdi, Z.; Comeau, M.R.; Jessup, H.K.; Yoon, B.R.; Brewer, A.; Chartier, S.; Paquette, N.; Ziegler, S.F.; Sarfati, M.; Delespesse, G. Thymic Stromal Lymphopoietin Is Released by Human Epithelial Cells in Response to Microbes, Trauma, or Inflammation and Potently Activates Mast Cells. J. Exp. Med. 2007, 204, 253-258. [CrossRef] [PubMed]

19. Okayama, Y.; Okumura, S.; Sagara, H.; Yuki, K.; Sasaki, T.; Watanabe, N.; Fueki, M.; Sugiyama, K.; Takeda, K.; Fukuda, T.; et al. Fcepsilonri-Mediated Thymic Stromal Lymphopoietin Production by Interleukin-4-Primed Human Mast Cells. Eur. Respir. J. 2009, 34, 425-435. [CrossRef]

20. Ebbo, M.; Crinier, A.; Vely, F.; Vivier, E. Innate Lymphoid Cells: Major Players in Inflammatory Diseases. Nat. Rev. Immunol. 2017, 17, 665-678. [CrossRef]

21. Verstraete, K.; Peelman, F.; Braun, H.; Lopez, J.; van Rompaey, D.; Dansercoer, A.; Vandenberghe, I.; Pauwels, K.; Tavernier, J.; Lambrecht, B.N.; et al. Structure and Antagonism of the Receptor Complex Mediated by Human Tslp in Allergy and Asthma. Nat. Commun. 2017, 8, 14937. [CrossRef] [PubMed]

22. Pandey, A.; Ozaki, K.; Baumann, H.; Levin, S.D.; Puel, A.; Farr, A.G.; Ziegler, S.F.; Leonard, W.J.; Lodish, H.F. Cloning of a Receptor Subunit Required for Signaling by Thymic Stromal Lymphopoietin. Nat. Immunol. 2000, 1, 59-64. [CrossRef] [PubMed]

23. Park, S.L.; Martin, U.; Garka, K.; Gliniak, B.; di Santo, J.P.; Muller, W.; Largaespada, D.A.; Copeland, N.G.; Jenkins, N.A.; Farr, A.G.; et al. Cloning of the Murine Thymic Stromal Lymphopoietin (Tslp) Receptor: Formation of a Functional Heteromeric Complex Requires Interleukin 7 Receptor. J. Exp. Med. 2000, 192, 659-670. [CrossRef]

24. Mena, M.A.; Langlois, A.; Speca, S.; Schneider, L.; Desreumaux, P.; Dubuquoy, L.; Bertin, B. The Expression of the Short Isoform of Thymic Stromal Lymphopoietin in the Colon Is Regulated by the Nuclear Receptor Peroxisome Proliferator Activated Receptor-Gamma and Is Impaired During Ulcerative Colitis. Front. Immunol. 2017, 8, 1052. [CrossRef] [PubMed]

25. Datta, A.; Alexander, R.; Sulikowski, M.G.; Nicholson, A.G.; Maher, T.M.; Scotton, C.J.; Chambers, R.C. Evidence for a Functional Thymic Stromal Lymphopoietin Signaling Axis in Fibrotic Lung Disease. J. Immunol. 2013, 191, 4867-4879. [CrossRef]

26. Xie, Y.; Takai, T.; Chen, X.; Okumura, K.; Ogawa, H. Long Tslp Transcript Expression and Release of Tslp Induced by Tlr Ligands and Cytokines in Human Keratinocytes. J. Dermatol. Sci. 2012, 66, 233-237. [CrossRef]

27. Kabata, H.; Moro, K.; Fukunaga, K.; Suzuki, Y.; Miyata, J.; Masaki, K.; Betsuyaku, T.; Koyasu, S.; Asano, K. Thymic Stromal Lymphopoietin Induces Corticosteroid Resistance in Natural Helper Cells During Airway Inflammation. Nat. Commun. 2013, 4, 2675. [CrossRef]

28. Protti, P.M.; de Monte, L. Thymic Stromal Lymphopoietin and Cancer: Th2-Dependent and -Independent Mechanisms. Front. Immunol. 2020, 11, 2088. [CrossRef]

29. Olkhanud, B.P.; Rochman, Y.; Bodogai, M.; Malchinkhuu, E.; Wejksza, K.; Xu, M.; Gress, R.E.; Hesdorffer, C.; Leonard, W.J.; Biragyn, A. Thymic Stromal Lymphopoietin Is a Key Mediator of Breast Cancer Progression. J. Immunol. 2011, 186, 5656-5662. [CrossRef]

30. Burkard-Mandel, L.; O'Neill, R.; Colligan, S.; Seshadri, M.; Abrams, S.I. Tumor-Derived Thymic Stromal Lymphopoietin Enhances Lung Metastasis through an Alveolar Macrophage-Dependent Mechanism. Oncoimmunology 2018, 7, e1419115. [CrossRef]

31. Kuan, L.E.; Ziegler, S.F. A Tumor-Myeloid Cell Axis, Mediated Via the Cytokines Il-1alpha and Tslp, Promotes the Progression of Breast Cancer. Nat. Immunol. 2018, 19, 366-374. [CrossRef]

32. Ragonnaud, E.; Moritoh, K.; Bodogai, M.; Gusev, F.; Garaud, S.; Chen, C.; Wang, X.; Baljinnyam, T.; Becker, K.G.; Maul, R.W.; et al. Tumor-Derived Thymic Stromal Lymphopoietin Expands Bone Marrow B-Cell Precursors in Circulation to Support Metastasis. Cancer Res. 2019, 79, 5826-5838. [CrossRef] 
33. De Monte, L.; Reni, M.; Tassi, E.; Clavenna, D.; Papa, I.; Recalde, H.; Braga, M.; di Carlo, V.; Doglioni, C.; Protti, M.P. Intratumor T Helper Type 2 Cell Infiltrate Correlates with Cancer-Associated Fibroblast Thymic Stromal Lymphopoietin Production and Reduced Survival in Pancreatic Cancer. J. Exp. Med. 2011, 208, 469-478. [CrossRef]

34. Lin, C.M.; Lin, L.W.; Chen, Y.W.; Ye, Y.L. The Expression and Prognostic Impact of Proinflammatory Cytokines and Their Associations with Carcinogens in Oropharyngeal Squamous Cell Carcinoma. Cancer Immunol. Immunother. 2020, 69, 549-558. [CrossRef]

35. Xu, L.; Guo, Y.; Xu, N.; Chen, L.; Zhu, J.; Liu, N.; Zhang, Z.Y. Overexpression of Thymic Stromal Lymphopoietin Is Correlated with Poor Prognosis in Epithelial Ovarian Carcinoma. Biosci. Rep. 2019, 39. [CrossRef] [PubMed]

36. Vizio, B.; Boita, M.; Cristiano, C.; Mazibrada, J.; Bosco, O.; Novarino, A.; Prati, A.; Sciascia, S.; Rolla, G.; Ciuffreda, L.; et al. Thymic Stromal Lymphopoietin in Human Pancreatic Ductal Adenocarcinoma: Expression and Prognostic Significance. Oncotarget 2018, 9, 32795-32809. [CrossRef] [PubMed]

37. Ferretti, E.; Hohaus, S.; di Napoli, A.; Belmonte, B.; Cuccaro, A.; Cupelli, E.; Galli, E.; Rufini, V.; Tripodi, G.; Fraternali-Orcioni, G.; et al. Interleukin-31 and Thymic Stromal Lymphopoietin Expression in Plasma and Lymph Node from Hodgkin Lymphoma Patients. Oncotarget 2017, 8, 85263-85275. [CrossRef] [PubMed]

38. Zhang, B.; Wei, C.Y.; Chang, K.K.; Yu, J.J.; Zhou, W.J.; Yang, H.L.; Shao, J.; Li, M.Q.; Xie, F. Tslp Promotes Angiogenesis of Human Umbilical Vein Endothelial Cells by Strengthening the Crosstalk between Cervical Cancer Cells and Eosinophils. Oncol. Lett. 2017, 14, 7483-7488. [CrossRef]

39. Zhou, W.J.; Yang, H.L.; Chang, K.K.; Meng, Y.; Wang, M.Y.; Yuan, M.M.; Li, M.Q.; Xie, F. Human Thymic Stromal Lymphopoietin Promotes the Proliferation and Invasion of Cervical Cancer Cells by Downregulating Microrna-132 Expression. Oncol. Lett. 2017, 14, 7910-7916. [CrossRef]

40. Takahashi, N.; Sugaya, M.; Suga, H.; Oka, T.; Kawaguchi, M.; Miyagaki, T.; Fujita, H.; Sato, S. Thymic Stromal Chemokine Tslp Acts through Th2 Cytokine Production to Induce Cutaneous T-Cell Lymphoma. Cancer Res. 2016, 76, 6241-6252. [CrossRef]

41. Barooei, R.; Mahmoudian, R.A.; Abbaszadegan, M.R.; Mansouri, A.; Gholamin, M. Evaluation of Thymic Stromal Lymphopoietin (Tslp) and Its Correlation with Lymphatic Metastasis in Human Gastric Cancer. Med. Oncol. 2015, 32, 217. [CrossRef]

42. Xie, F.; Liu, L.B.; Shang, W.Q.; Chang, K.K.; Meng, Y.H.; Mei, J.; Yu, J.J.; Li, D.J.; Li, M.Q. The Infiltration and Functional Regulation of Eosinophils Induced by Tslp Promote the Proliferation of Cervical Cancer Cell. Cancer Lett. 2015, 364, 106-117. [CrossRef]

43. Watanabe, J.; Saito, H.; Miyatani, K.; Ikeguchi, M.; Umekita, Y. Tslp Expression and High Serum Tslp Level Indicate a Poor Prognosis in Gastric Cancer Patients. Yonago Acta Med. 2015, 58, 137-143.

44. Xie, F.; Meng, Y.H.; Liu, L.B.; Chang, K.K.; Li, H.; Li, M.Q.; Li, D.J. Cervical Carcinoma Cells Stimulate the Angiogenesis through Tslp Promoting Growth and Activation of Vascular Endothelial Cells. Am. J. Reprod. Immunol. 2013, 70, 69-79. [CrossRef]

45. Pedroza-Gonzalez, A.; Xu, K.; Wu, T.C.; Aspord, C.; Tindle, S.; Marches, F.; Gallegos, M.; Burton, E.C.; Savino, D.; Hori, T.; et al. Thymic Stromal Lymphopoietin Fosters Human Breast Tumor Growth by Promoting Type 2 Inflammation. J. Exp. Med. 2011, 208, 479-490. [CrossRef] [PubMed]

46. Li, H.; Zhao, H.; Yu, J.; Su, Y.; Cao, S.; An, X.; Ren, X. Increased Prevalence of Regulatory T Cells in the Lung Cancer Microenvironment: A Role of Thymic Stromal Lymphopoietin. Cancer Immunol. Immunother. 2011, 60, 1587-1596. [CrossRef] [PubMed]

47. Demehri, S.; Cunningham, T.J.; Manivasagam, S.; Ngo, K.H.; Tuchayi, S.M.; Reddy, R.; Meyers, M.A.; DeNardo, D.G.; Yokoyama, W.M. Thymic stromal lymphopoietin blocks early stages of breast carcinogenesis. J. Clin. Investig. 2016, 126, 1458-1470. [CrossRef] [PubMed]

48. Yue, W.; Lin, Y.; Yang, X.; Li, B.; Liu, J.; He, R. Thymic stromal lymphopoietin (TSLP) inhibits human colon tumor growth by promoting apoptosis of tumor cells. Oncotarget 2016, 7, 16840-16854. [CrossRef] [PubMed]

49. Cipolat, S.; Hoste, E.; Natsuga, K.; Quist, S.R.; Watt, F.M. Epidermal Barrier Defects Link Atopic Dermatitis with Altered Skin Cancer Susceptibility. eLife 2014, 3, e01888. [CrossRef] [PubMed]

50. Demehri, S.; Turkoz, A.; Manivasagam, S.; Yockey, L.J.; Turkoz, M.; Kopan, R. Elevated Epidermal Thymic Stromal Lymphopoietin Levels Establish an Antitumor Environment in the Skin. Cancer Cell 2012, 22, 494-505. [CrossRef] [PubMed]

51. Di Piazza, M.; Nowell, C.S.; Koch, U.; Durham, A.D.; Radtke, F. Loss of Cutaneous Tslp-Dependent Immune Responses Skews the Balance of Inflammation from Tumor Protective to Tumor Promoting. Cancer Cell 2012, 22, 479-493. [CrossRef]

52. Zhao, Y.; Zou, W.; Du, J. The Origins and Homeostasis of Monocytes and Tissue-Resident Macrophages in Physiological Situation. J. Cell Physiol. 2018, 233, 6425-6439. [CrossRef]

53. Davies, L.C.; Jenkins, S.J.; Allen, J.E.; Taylor, P.R. Tissue-Resident Macrophages. Nat. Immunol. 2013, 14, 986-995. [CrossRef] [PubMed]

54. Locati, M.; Curtale, G.; Mantovani, A. Diversity, Mechanisms, and Significance of Macrophage Plasticity. Annu. Rev. Pathol. 2020, 15, 123-147. [CrossRef] [PubMed]

55. Galli, S.J.; Borregaard, N.; Wynn, T.A. Phenotypic and functional plasticity of cells of innate immunity: Macrophages, mast cells and neutrophils. Nat. Immunol. 2011, 12, 1035-1044. [CrossRef]

56. Kataru, R.P.; Jung, K.; Jang, C.; Yang, H.; Schwendener, R.A.; Baik, J.E.; Han, S.H.; Alitalo, K.; Koh, G.Y. Critical role of CD11b+ macrophages and VEGF in inflammatory lymphangiogenesis, antigen clearance, and inflammation resolution. Blood 2009, 113, 5650-5659. [CrossRef] 
57. Granata, F.; Frattini, A.; Loffredo, S.; Staiano, R.I.; Petraroli, A.; Ribatti, D.; Oslund, R.; Gelb, M.H.; Lambeau, G.; Marone, G.; et al. Production of Vascular Endothelial Growth Factors from Human Lung Macrophages Induced by Group IIA and Group X Secreted Phospholipases A2. J. Immunol. 2010, 184, 5232-5241. [CrossRef]

58. Suh, S.H.; Choe, K.; Hong, S.P.; Jeong, S.; Makinen, T.; Kim, K.S.; Alitalo, K.; Surh, C.D.; Koh, G.Y.; Song, J. Gut microbiota regulates lacteal integrity by inducing VEGF-C in intestinal villus macrophages. EMBO Rep. 2019, 20. [CrossRef] [PubMed]

59. Staiano, R.I.; Loffredo, S.; Borriello, F.; Iannotti, F.; Piscitelli, F.; Orlando, P.; Secondo, A.; Granata, F.; Lepore, M.T.; Fiorelli, A.; et al. Human lung-resident macrophages express CB1 and CB2 receptors whose activation inhibits the release of angiogenic and lymphangiogenic factors. J. Leukoc. Biol. 2016, 99, 531-540. [CrossRef] [PubMed]

60. Ferrari, S.M.; Fallahi, P.; Galdiero, M.R.; Ruffilli, I.; Elia, G.; Ragusa, F.; Paparo, S.R.; Patrizio, A.; Mazzi, V.; Varricchi, G.; et al. Immune and Inflammatory Cells in Thyroid Cancer Microenvironment. Int. J. Mol. Sci. 2019, 20, 4413. [CrossRef] [PubMed]

61. De Palma, M.; Lewis, C.E. Macrophage Regulation of Tumor Responses to Anticancer Therapies. Cancer Cell 2013, 23, 277-286. [CrossRef]

62. Ruffell, B.; Affara, N.I.; Coussens, L.M. Differential macrophage programming in the tumor microenvironment. Trends Immunol. 2012, 33, 119-126. [CrossRef]

63. Ginhoux, F.; Guilliams, M. Tissue-Resident Macrophage Ontogeny and Homeostasis. Immunity 2016, 44, 439-449. [CrossRef]

64. Gordon, S.; Plüddemann, A. Tissue macrophages: Heterogeneity and functions. BMC Biol. 2017, 15, 53. [CrossRef] [PubMed]

65. Mould, K.J.; Barthel, L.; Mohning, M.P.; Thomas, S.M.; McCubbrey, A.L.; Danhorn, T.; Leach, S.M.; Fingerlin, T.E.; O'Connor, B.P.; Reisz, J.A.; et al. Cell Origin Dictates Programming of Resident versus Recruited Macrophages during Acute Lung Injury. Am. J. Respir. Cell Mol. Biol. 2017, 57, 294-306. [CrossRef] [PubMed]

66. Chakarov, S.; Lim, H.Y.; Tan, L.; Lim, S.Y.; See, P.; Lum, J.; Zhang, X.-M.; Foo, S.; Nakamizo, S.; Duan, K.; et al. Two distinct interstitial macrophage populations coexist across tissues in specific subtissular niches. Science 2019, 363, eaau0964. [CrossRef] [PubMed]

67. Russell, D.G.; Huang, L.; VanderVen, B. Immunometabolism at the interface between macrophages and pathogens. Nat. Rev. Immunol. 2019, 19, 291-304. [CrossRef]

68. Epelman, S.; Lavine, K.J.; Beaudin, A.E.; Sojka, D.K.; Carrero, J.A.; Calderon, B.; Brija, T.; Gautier, E.; Ivanov, S.; Satpathy, A.; et al. Embryonic and Adult-Derived Resident Cardiac Macrophages Are Maintained through Distinct Mechanisms at Steady State and during Inflammation. Immunity 2014, 40, 91-104. [CrossRef]

69. Travaglini, K.J.; Nabhan, A.N.; Penland, L.; Sinha, R.; Gillich, A.; Sit, R.V.; Chang, S.; Conley, S.D.; Mori, Y.; Seita, J.; et al. A Molecular Cell Atlas of the Human Lung from Single-Cell Rna Sequencing. Nature 2020, 587, 619-625. [CrossRef]

70. Lavin, Y.; Kobayashi, S.; Leader, A.; Amir, E.-A.D.; Elefant, N.; Bigenwald, C.; Remark, R.; Sweeney, R.; Becker, C.D.; Levine, J.H.; et al. Innate Immune Landscape in Early Lung Adenocarcinoma by Paired Single-Cell Analyses. Cell 2017, 169, 750-765.e17. [CrossRef]

71. Zilionis, R.; Engblom, C.; Pfirschke, C.; Savova, V.; Zemmour, D.; Saatcioglu, H.D.; Krishnan, I.; Maroni, G.; Meyerovitz, C.V.; Kerwin, C.M.; et al. Single-Cell Transcriptomics of Human and Mouse Lung Cancers Reveals Conserved Myeloid Populations across Individuals and Species. Immunity 2019, 50, 1317-1334.e10. [CrossRef] [PubMed]

72. Mukaida, N.; Nosaka, T.; Nakamoto, Y.; Baba, T. Lung Macrophages: Multifunctional Regulator Cells for Metastatic Cells. Int. J. Mol. Sci. 2018, 20, 116. [CrossRef]

73. DeNardo, D.G.; Ruffell, B. Macrophages as regulators of tumour immunity and immunotherapy. Nat. Rev. Immunol. 2019, 19, 369-382. [CrossRef]

74. Balestrieri, B.; Granata, F.; Loffredo, S.; Petraroli, A.; Scalia, G.; Morabito, P.; Cardamone, C.; Varricchi, G.; Triggiani, M. Phenotypic and Functional Heterogeneity of Low-Density and High-Density Human Lung Macrophages. Biomedicines 2021, 9, 505. [CrossRef] [PubMed]

75. Ferrara, A.L.; Galdiero, M.R.; Fiorelli, A.; Cristinziano, L.; Granata, F.; Marone, G.; Di Crescenzo, R.M.; Braile, M.; Marcella, S.; Modestino, L.; et al. Macrophage-polarizing stimuli differentially modulate the inflammatory profile induced by the secreted phospholipase A2 group IA in human lung macrophages. Cytokine 2021, 138, 155378. [CrossRef]

76. Borriello, F.; Iannone, R.; Di Somma, S.; Vastolo, V.; Petrosino, G.; Visconte, F.; Raia, M.; Scalia, G.; Loffredo, S.; Varricchi, G.; et al. Lipopolysaccharide-Elicited TSLPR Expression Enriches a Functionally Discrete Subset of Human CD14 ${ }^{+} \mathrm{CD} 1 \mathrm{c}^{+} \mathrm{Monocytes}$. J. Immunol. 2017, 198, 3426-3435. [CrossRef]

77. Loffredo, S.; Borriello, F.; Iannone, R.; Ferrara, A.L.; Galdiero, M.R.; Gigantino, V.; Esposito, P.; Varricchi, G.; Lambeau, G.; Cassatella, M.A.; et al. Group V Secreted Phospholipase A2 Induces the Release of Proangiogenic and Antiangiogenic Factors by Human Neutrophils. Front. Immunol. 2017, 8, 443. [CrossRef] [PubMed]

78. Perry, R.P.; Kelley, D.E. Inhibition of Rna Synthesis by Actinomycin D: Characteristic Dose-Response of Different Rna Species. J. Cell Physiol. 1970, 76, 127-139. [CrossRef]

79. Braga, F.A.V.; Kar, G.; Berg, M.; Carpaij, O.A.; Polański, K.; Simon, L.M.; Brouwer, S.; Gomes, T.; Hesse, L.; Jiang, J.; et al. A cellular census of human lungs identifies novel cell states in health and in asthma. Nat. Med. 2019, 25, 1153-1163. [CrossRef]

80. Allard, B.; Panariti, A.; Martin, J.G. Alveolar Macrophages in the Resolution of Inflammation, Tissue Repair, and Tolerance to Infection. Front. Immunol. 2018, 9, 1777. [CrossRef] 
81. Li, Z.; Maeda, D.; Yoshida, M.; Umakoshi, M.; Nanjo, H.; Shiraishi, K.; Saito, M.; Kohno, T.; Konno, H.; Saito, H.; et al. The intratumoral distribution influences the prognostic impact of CD68- and CD204-positive macrophages in non-small cell lung cancer. Lung Cancer 2018, 123, 127-135. [CrossRef]

82. Singhal, S.; Stadanlick, J.; Annunziata, M.J.; Rao, A.S.; Bhojnagarwala, P.S.; O’Brien, S.; Moon, E.K.; Cantu, E.; Danet-Desnoyers, G.; Ra, H.-J.; et al. Human tumor-associated monocytes/macrophages and their regulation of T cell responses in early-stage lung cancer. Sci. Transl. Med. 2019, 11, eaat1500. [CrossRef] [PubMed]

83. Sumitomo, R.; Hirai, T.; Fujita, M.; Murakami, H.; Otake, Y.; Huang, C. M2 tumor-associated macrophages promote tumor progression in non-small-cell lung cancer. Exp. Ther. Med. 2019. [CrossRef]

84. Pierce, B.L.; Ballard-Barbash, R.; Bernstein, L.; Baumgartner, R.N.; Neuhouser, M.L.; Wener, M.H.; Baumgartner, K.B.; Gilliland, F.D.; Sorensen, B.E.; McTiernan, A.; et al. Elevated Biomarkers of Inflammation Are Associated With Reduced Survival Among Breast Cancer Patients. J. Clin. Oncol. 2009, 27, 3437-3444. [CrossRef]

85. Barkan, D.; El Touny, L.H.; Michalowski, A.M.; Smith, J.A.; Chu, I.; Davis, A.; Webster, J.D.; Hoover, S.; Simpson, R.M.; Gauldie, J.; et al. Metastatic Growth from Dormant Cells Induced by a Col-I-Enriched Fibrotic Environment. Cancer Res. 2010, 70, 5706-5716. [CrossRef] [PubMed]

86. Albrengues, J.; Shields, M.A.; Ng, D.; Park, C.G.; Ambrico, A.; Poindexter, M.E.; Upadhyay, P.; Uyeminami, D.L.; Pommier, A.; Küttner, V.; et al. Neutrophil extracellular traps produced during inflammation awaken dormant cancer cells in mice. Science 2018, 361, eaao4227. [CrossRef]

87. Aspord, C.; Pedroza-Gonzalez, A.; Gallegos, M.; Tindle, S.; Burton, E.C.; Su, D.; Marches, F.; Banchereau, J.; Palucka, A.K. Breast cancer instructs dendritic cells to prime interleukin 13-secreting $\mathrm{CD} 4^{+} \mathrm{T}$ cells that facilitate tumor development. J. Exp. Med. 2007, 204, 1037-1047. [CrossRef]

88. Marone, G.; Granata, F.; Pucino, V.; Pecoraro, A.; Heffler, E.; Loffredo, S.; Scadding, G.W.; Varricchi, G. The Intriguing Role of Interleukin 13 in the Pathophysiology of Asthma. Front. Pharmacol. 2019, 10, 1387. [CrossRef]

89. Ferrando, M.; Bagnasco, D.; Varricchi, G.; Bernardi, S.; Bragantini, A.; Passalacqua, G.; Canonica, G.W. Personalized Medicine in Allergy. Allergy Asthma Immunol. 2017, 9, 15-24. [CrossRef] [PubMed]

90. Cao, H.; Zhang, J.; Liu, H.; Wan, L.; Zhang, H.; Huang, Q.; Xu, E.; Lai, M. Il-13/Stat6 Signaling Plays a Critical Role in the Epithelial-Mesenchymal Transition of Colorectal Cancer Cells. Oncotarget 2016, 7, 61183-61198. [CrossRef] [PubMed]

91. Gandhi, A.N.; Bennett, B.L.; Graham, N.M.; Pirozzi, G.; Stahl, N.; Yancopoulos, G.D. Targeting Key Proximal Drivers of Type 2 Inflammation in Disease. Nat. Rev. Drug Discov. 2016, 15, 35-50. [CrossRef] [PubMed]

92. Munitz, A.; Brandt, E.; Mingler, M.; Finkelman, F.D.; Rothenberg, M.E. Distinct roles for IL-13 and IL-4 via IL-13 receptor 1 and the type II IL-4 receptor in asthma pathogenesis. Proc. Natl. Acad. Sci. USA 2008, 105, 7240-7245. [CrossRef]

93. Wilson, C.B.; Rowell, E.; Sekimata, M. Epigenetic Control of T-Helper-Cell Differentiation. Nat. Rev. Immunol. 2009, 9, 91-105. [CrossRef]

94. Gour, N.; Wills-Karp, M. Il-4 and Il-13 Signaling in Allergic Airway Disease. Cytokine 2015, 75, 68-78. [CrossRef] [PubMed]

95. Finkelman, D.F.; Shea-Donohue, T.; Morris, S.C.; Gildea, L.; Strait, R.; Madden, K.B.; Schopf, L.; Urban, J.F., Jr. Interleukin-4- and Interleukin-13-Mediated Host Protection against Intestinal Nematode Parasites. Immunol. Rev. 2004, 201, 139-155. [CrossRef]

96. Grünig, G.; Warnock, M.; Wakil, A.E.; Venkayya, R.; Brombacher, F.; Rennick, D.M.; Sheppard, D.; Mohrs, M.; Donaldson, D.D.; Locksley, R.M.; et al. Requirement for IL-13 Independently of IL-4 in Experimental Asthma. Science 1998, 282, $2261-2263$. [CrossRef] [PubMed]

97. Perkins, C.; Wills-Karp, M.; Finkelman, F.D. Il-4 Induces Il-13-Independent Allergic Airway Inflammation. J. Allergy Clin. Immunol. 2006, 118, 410-419. [CrossRef]

98. Han, H.; Headley, M.B.; Xu, W.; Comeau, M.R.; Zhou, B.; Ziegler, S.F. Thymic Stromal Lymphopoietin Amplifies the Differentiation of Alternatively Activated Macrophages. J. Immunol. 2013, 190, 904-912. [CrossRef]

99. Moorehead, A.; Hanna, R.; Heroux, D.; Neighbour, H.; Sandford, A.; Gauvreau, G.M.; Sommer, D.D.; Denburg, J.A.; Akhabir, L. A Thymic Stromal Lymphopoietin Polymorphism May Provide Protection from Asthma by Altering Gene Expression. Clin. Exp. Allergy 2020, 50, 471-478. [CrossRef]

100. Ying, S.; O'Connor, B.; Ratoff, J.; Meng, Q.; Mallett, K.; Cousins, D.; Robinson, D.; Zhang, G.; Zhao, J.; Lee, T.; et al. Thymic Stromal Lymphopoietin Expression Is Increased in Asthmatic Airways and Correlates with Expression of Th2-Attracting Chemokines and Disease Severity. J. Immunol. 2005, 174, 8183-8190. [CrossRef]

101. Ying, S.; O'Connor, B.; Ratoff, J.; Meng, Q.; Fang, C.; Cousins, D.; Zhang, G.; Gu, S.; Gao, Z.; Shamji, B.; et al. Expression and Cellular Provenance of Thymic Stromal Lymphopoietin and Chemokines in Patients with Severe Asthma and Chronic Obstructive Pulmonary Disease. J. Immunol. 2008, 181, 2790-2798. [CrossRef]

102. Gauvreau, G.M.; O’Byrne, P.M.; Boulet, L.-P.; Wang, Y.; Cockcroft, D.; Bigler, J.; Fitzgerald, J.M.; Boedigheimer, M.; Davis, B.E.; Dias, C.; et al. Effects of an Anti-TSLP Antibody on Allergen-Induced Asthmatic Responses. N. Engl. J. Med. 2014, 370, $2102-2110$. [CrossRef]

103. Corren, J.; Parnes, J.R.; Wang, L.; Mo, M.; Roseti, S.L.; Griffiths, J.M.; van der Merwe, R. Tezepelumab in Adults with Uncontrolled Asthma. N. Engl. J. Med. 2017, 377, 936-946. [CrossRef] [PubMed]

104. Lai, F.J.; Thompson, L.J.; Ziegler, S.F. Tslp Drives Acute Th2-Cell Differentiation in Lungs. J. Allergy Clin. Immunol. 2020, 146, 1406-1418.e7. [CrossRef] [PubMed] 
105. Robinson, D.; Humbert, M.; Buhl, R.; Cruz, A.A.; Inoue, H.; Korom, S.; Hanania, N.A.; Nair, P. Revisiting Type 2-high and Type 2-low airway inflammation in asthma: Current knowledge and therapeutic implications. Clin. Exp. Allergy 2017, 47, 161-175. [CrossRef]

106. Wenzel, S.E. Asthma Phenotypes: The Evolution from Clinical to Molecular Approaches. Nat. Med. 2012, 18, 716-725. [CrossRef]

107. Reyfman, P.A.; Walter, J.M.; Joshi, N.; Anekalla, K.R.; McQuattie-Pimentel, A.C.; Chiu, S.; Fernandez, R.; Akbarpour, M.; Chen, C.-I.; Ren, Z.; et al. Single-Cell Transcriptomic Analysis of Human Lung Provides Insights into the Pathobiology of Pulmonary Fibrosis. Am. J. Respir. Crit. Care Med. 2019, 199, 1517-1536. [CrossRef]

108. Loffredo, S.; Bova, M.; Suffritti, C.; Borriello, F.; Zanichelli, A.; Petraroli, A.; Varricchi, G.; Triggiani, M.; Cicardi, M.; Marone, G. Elevated plasma levels of vascular permeability factors in C1 inhibitor-deficient hereditary angioedema. Allergy 2016, 71, 989-996. [CrossRef] [PubMed]

109. Cristinziano, L.; Poto, R.; Criscuolo, G.; Ferrara, A.L.; Galdiero, M.R.; Modestino, L.; Loffredo, S.; De Paulis, A.; Marone, G.; Spadaro, G.; et al. IL-33 and Superantigenic Activation of Human Lung Mast Cells Induce the Release of Angiogenic and Lymphangiogenic Factors. Cells 2021, 10, 145. [CrossRef]

110. Marone, G.; Rossi, F.W.; Pecoraro, A.; Pucino, V.; Criscuolo, G.; De Paulis, A.; Spadaro, G.; Marone, G.; Varricchi, G. HIV gp120 Induces the Release of Proinflammatory, Angiogenic, and Lymphangiogenic Factors from Human Lung Mast Cells. Vaccines 2020, 8, 208. [CrossRef] [PubMed]

111. Varricchi, G.; Loffredo, S.; Borriello, F.; Pecoraro, A.; Rivellese, F.; Genovese, A.; Spadaro, G.; Marone, G. Superantigenic Activation of Human Cardiac Mast Cells. Int. J. Mol. Sci. 2019, 20, 1828. [CrossRef] [PubMed]

112. Varricchi, G.; Loffredo, S.; Galdiero, M.R.; Marone, G.; Cristinziano, L.; Granata, F.; Marone, G. Innate effector cells in angiogenesis and lymphangiogenesis. Curr. Opin. Immunol. 2018, 53, 152-160. [CrossRef] [PubMed]

113. Ohara, M.; Yamaguchi, Y.; Matsuura, K.; Murakami, S.; Arihiro, K.; Okada, M. Possible involvement of regulatory T cells in tumor onset and progression in primary breast cancer. Cancer Immunol. Immunother. 2008, 58, 441-447. [CrossRef]

114. Strauss, L.; Bergmann, C.; Szczepanski, M.J.; Gooding, W.E.; Johnson, J.T.; Whiteside, T.L. A Unique Subset of CD4+CD25highFoxp3+ T Cells Secreting Interleukin-10 and Transforming Growth Factor- $\beta 1$ Mediates Suppression in the Tumor Microenvironment. Clin. Cancer Res. 2007, 13, 4345-4354. [CrossRef] [PubMed]

115. Lo Kuan, E.; Ziegler, S.F. Thymic Stromal Lymphopoietin and Cancer. J. Immunol. 2014, 193, 4283-4288. [CrossRef]

116. Marone, G.; Spadaro, G.; Braile, M.; Poto, R.; Criscuolo, G.; Pahima, H.; Loffredo, S.; Levi-Schaffer, F.; Varricchi, G. Tezepelumab: A novel biological therapy for the treatment of severe uncontrolled asthma. Expert Opin. Investig. Drugs 2019, 28, 931-940. [CrossRef]

117. Gauvreau, G.M.; Sehmi, R.; Ambrose, C.S.; Griffiths, J.M. Thymic stromal lymphopoietin: Its role and potential as a therapeutic target in asthma. Expert Opin. Ther. Targets 2020, 24, 777-792. [CrossRef]

118. Shi, C.; Pamer, E.G. Monocyte Recruitment During Infection and Inflammation. Nat. Rev. Immunol. 2011, 11, 762-774. [CrossRef]

119. Bjerkan, L.; Schreurs, O.J.F.; Engen, S.A.; Jahnsen, F.L.; Baekkevold, E.S.; Blix, I.J.S.; Schenck, K. The short form of TSLP is constitutively translated in human keratinocytes and has characteristics of an antimicrobial peptide. Mucosal Immunol. 2015, 8, 49-56. [CrossRef] 